\title{
Douglass North's Theory of Institutions: Lessons for Law and Development
}

\author{
Julio Faundez ${ }^{1}$
}

Published online: 25 July 2016

(C) The Author(s) 2016. This article is published with open access at Springerlink.com

\begin{abstract}
This paper offers a critical overview and assessment of North's work on institutions and economic change, focusing on aspects of his work that are of interest to law and development scholars. It examines North's approach to institutions through his historical work focusing on his concept of credible commitment and his interpretation of the effect of the Glorious Revolution on property rights, focusing especially on the role he assigns to property rights in bringing about the Industrial Revolution. The paper also examines North's theory of institutions focusing on three main issues: the pervasive influence of the principles of neoclassical economics; the focus on an end-point model based on successful Western economies; and the failure adequately to account for the role of organizations in the process of change. Finally, the paper discusses the role of law in North's theory. The objective of this section of the paper is to clarify whether law, according to North is a protagonist in the process of institutional change or is merely a by-product of changes taking place elsewhere in society.
\end{abstract}

Keywords Law and development · Institutions · New institutional economics · Political development

\section{Introduction}

Over the past four decades an influential group of economists - known under the label New Institutional Economics (NIE) - have focused their attention on the role of institutions. While their research centres mainly on issues relating to developed market economies, some of them have devoted their attention to the study of the role of institutions in economic growth. Douglass North (1920-2015), an economic

Julio Faundez

j.faundez@warwick.ac.uk

1 University of Warwick, Coventry, UK 
historian who in 1993 won the Nobel Memorial Prize in Economics, was one the most prominent member of this group. ${ }^{1}$

North had a major impact on contemporary development thinking. His work was the single most important source of inspiration that led development agencies in the early 1990s to shift their attention from technical economic issues towards broader institutional concerns. This shift, reflected in the World Bank's motto 'institutions matter', brought about a substantial increase in the resources that international development agencies allocate to legal and institutional reform. But it is as a scholar that North had the most profound and lasting impact. His work is highly respected by economists and is hugely influential among political scientists, historians and sociologists. The impact of his work among academics from a wide range of disciplines is a reflection of his broad interdisciplinary perspective, which spans, with rigour and erudition, a range of disciplines. Regrettably, however, with few exceptions, ${ }^{2}$ legal scholars interested in law and development and socio-legal studies have largely ignored his work.

The indifference of law and development scholars to North's work is unjustified. Indeed, his work addresses issues and offers explanations and insights to questions that have long been on their research agenda. Although North did not purport to offer simple solutions to longstanding questions about economic growth, his work deserves attention because it attempts to explain the role of institutions, including law, in the process of economic change. In particular, his work should be of interest to lawyers because it addresses many questions that figure prominently on the research agendas of legal scholars, including the following: How does sustained institutional change occur and what role, if any, does law play in this process? What is the relationship between political and legal processes? Why do some countries find it so difficult to establish stable institutions to protect property rights and enforce contracts? What is the relationship between legitimacy and efficiency? What role do culture and ideology play in institutional development? Why are formal laws often ineffective? Are some legal systems more economically efficient than others? Does the enactment of modern constitutions make a difference to political and economic processes? Although North's answers to these questions was coloured by his distinctive economic approach, they provide law and development and socio-legal scholars with valuable material for reflection.

Since North's work is so obviously relevant to the research interests of law and development and socio-legal scholars, why has it been ignored? There are, of course, no sound academic reasons to explain this. Perhaps the neglect is due to the fact that North was identified, albeit mistakenly, as an advocate of the controversial Washington Consensus and, as a consequence, regarded as politically biased by critics of neo- liberal policies. Such a view is unfair because it fails to take into account that he was a sharp critic of the simplistic advice promoted by World Bank economists, who believe that all that is needed to resolve the problem of growth is to get the prices right. North's theory of institutions was precisely designed to show

\footnotetext{
${ }^{1}$ On NIE see, p. Alston (2008); Eggertsson (1990); Field (1999); Furubotn and Richter (2005); Ménard and Shirley (2005); Ménard and Shirley (2012); Mercuro and Medema (2006, pp. 241-283); Rutherford (1994).

2 Dam (2006); Thomas (2011); Trebilcock and Daniels (2008).
} 
that this approach was misguided. Nevertheless, the view that he is an unconditional supporter of the Washington Consensus is not easy to rebut because the Bank - for reasons that even North might not have entirely comprehended - selectively embraced some of his ideas, in particular his definition of institutions as rules of the game and his argument that sustained growth is not possible without appropriate institutions. ${ }^{3}$

North's work undoubtedly poses serious challenges to the non-specialist reader. Since his main concern was to persuade other economists about the limitations of economic models that take institutions for granted, lawyers are unlikely to find his work relevant. Also, his work is not immediately accessible, as it is dispersed in numerous publications spanning a period of several decades. Over the years he modified and refined some of his theoretical positions. As a result, understanding and summarising his theory on institutions is not a simple task. ${ }^{4}$ Moreover, as this paper shows, on some crucial points, his position was sometimes vague, often evasive or not fully developed. Although, in general, he presented his ideas clearly, his writing was perhaps too succinct. As a result, his readers frequently find themselves wishing he had offered a fuller explanation of his theoretical concepts or provided a more detailed discussion of his historical illustrations. His most ambitious and successful book, Institutions, Institutional Change, and Economic Performance (1990), which presents a general theory about institutions, is only 152 pages long so, unsurprisingly, the book can hardly offer in-depth analysis of all the issues. According to Alexander Field, some ambiguities in North's work stemmed from his determined efforts to present a theory that was sufficiently eclectic to draw into his camp a wide range of scholars and perspectives. ${ }^{5}$

This paper offers a critical overview and assessment of North's work on institutions and economic change, focusing on aspects of his work that are of interest to law and development scholars. The paper consists of five sections. Section 2 examines North's approach to institutions through his historical work. It discusses his concept of credible commitment and focuses especially on his interpretation of the effect of the Glorious Revolution on property rights and the role he assigns to property rights in bringing about the Industrial Revolution. Section 3 examines North's theory of institutions, as reflected in his major theoretical books: Institutions, Institutional Change, and Economic Performance (1990); Understanding the Process of Economic Change (2005); and Violence and Social Orders (2009). It focuses on three related features: the pervasive influence of the principles of neoclassical economics; the exclusive focus on an end-point model based on successful Western economies; and the reluctance to account for the role of organizations in the process of change. Section 4 discusses the role of law in North's theory. Its objective is to clarify whether, in his theory, law is a protagonist in the process of institutional change or subordinate to economic and political processes. The final section. Section 5, concludes and draws together some of the points developed in the paper.

\footnotetext{
${ }^{3}$ Kleinfeld (2012, pp. 86-87).

${ }^{4}$ For overviews of his work, see Bates (2014); Field (2006); Greif (2008); Ménard and Shirley (2014).

${ }^{5}$ Field (2006, p. 425).
} 


\section{History}

North's interest in institutions originated from his extensive work in economic history, as apparent in his two major books on European economic history: The Rise of the Western World - A New Economic History (1973) and Structure and Change in Economic History (1981). The main lesson he draws from this work is that sustained economic growth requires an efficient system of property rights so that individuals can channel their efforts into activities that will bring private returns close to the social rate of return. The way economies move towards achieving better institutions is through a process of adaptive efficiency. The focus of adaptive efficiency is on the rules that shape economic evolution over time and on the willingness of its players to acquire knowledge and skills to develop innovative solutions for resolving problems. ${ }^{6}$ Adaptive efficiency brings about improvements to the overall institutional structure, but it is also conditioned by it. The test that North proposes to determine whether an economy is moving in an adaptively efficient direction is whether its institutions provide 'the incentives to encourage the development of decentralized decision-making processes that will allow societies to maximize the efforts required to explore alternative ways of resolving problems'. ${ }^{7}$ The most important illustration of adaptive efficiency is the transition from feudalism to capitalism, which took place in late medieval and early modern Europe. In historical terms adaptive efficiency is incremental and consists of cumulative changes brought about by individuals who encourage other individuals to strive for greater productivity that eventually yields positive social change. This was the kind of institutional transformation that brought about the prevalence of market relations and the Industrial Revolution in Northern Europe. ${ }^{8}$

The transition in Europe occurred over a long period. It was the product of a mix of economic and political changes that combined to produce an enduring economic outcome. Briefly, North's characterisation of this period is as follows. ${ }^{9}$ In the fourteenth century, contracts between lords and peasants were altered, albeit incrementally, as a result of the sharp decline in population, which, in turn, brought about changes to the parties' relative bargaining position. The nature and extent of the alterations to these contracts were determined by transaction costs, as reflected in the customary rules prevailing in the manor and in the parties' perceptions about their unequal relationship, which the parties - lords and peasants - took for granted. Had the parties not taken for granted the unequal nature of their contractual relationship, they would have opted for a more radical and more efficient renegotiation. The path-dependent attribute of institutions led them towards incremental change. In this instance, the outcome was efficient because of the combination of competitive political forces and the slow ideological shift away from the unequal character of the master-servant relationship. As a consequence, North argues, feudalism was not an exploitative arrangement, but an efficient solution that

\footnotetext{
6 North (1990a, p. 80).

7 North (1990a, p. 81).

8 North (1971, p. 123).

9 North and Thomas (1971, 1973, pp. 25-32).
} 
contributed to reduce transaction costs in response to the needs of peasants. In his view, the costs involved in negotiating rental agreements were so high that labour services proved to be a more efficient alternative. ${ }^{10}$ North's characterisation of medieval serfdom as an efficient contractual relationship was strongly criticised. ${ }^{11}$ Arcadius Kahan noted that the depiction of serfdom as contractual was misleading because serfdom, as an institution, was not a relationship of equality, but partial ownership of human beings. He also noted that it was a mistake to describe as contractual an arrangement where only one of the parties had the final say on the nature of the relationship. ${ }^{12}$ North accepted these criticisms and in 1981 abandoned the concept of the manorial regime as a contractual relationship, describing it instead as a predatory relationship whereby lords extracted income from the peasants in a manner analogous to that employed by the mafia. ${ }^{13}$ He noted, however, that the demise of the manorial system came about because of the changing opportunity costs of lords and peasants. ${ }^{14}$

North's interpretation of the manorial system highlights the link between economic and political processes, but does not purport to explain how this link operates in contemporary societies. In general, he regards institutional change as slow and unlikely to lead to economic growth because those who benefit from the status quo will sabotage or strongly resist it. He also rules out a Leninist type of revolution from above because he believes that cultural factors or, as he describes them, informal social rules, generally tend to defeat the efforts of the most zealous revolutionaries. ${ }^{15}$ Only institutions that promote cooperation are capable of overcoming the elites' vested interests. The difficulty, in his view, is that political institutions are generally fragile and thus fail to guarantee either stability or sustained growth. Political democracy would seem to provide the most efficient framework because it gives access to decision-making to a large proportion of the population and has mechanisms to keep in check rulers' tendencies towards arbitrary rule. Yet, democracy does not guarantee the harmonisation of political markets. Two factors undermine democracy: the complexity of modern societies, exacerbated by voters' ignorance; and, the perennial principal-agent problem, which means that political actors' (agents) agendas are not generally consistent with the wishes and interests of the voters (principals). ${ }^{16}$ Nevertheless, successful political outcomes can be achieved provided the parties agree to cooperate and their commitment is credible. ${ }^{17}$

The notion of credible commitment was one of North's most celebrated contributions, but its meaning is unclear. It refers mainly to the enforcement of

\footnotetext{
${ }^{10}$ North and Thomas (1973; p. 32), (1971, p. 790/1).

11 Jones (1972); Fenoaltea (1975a, b); Field (1981); Hicks (1974); Jones (1972); Rinngrose (1973).

12 Kahan (1973, pp. 89, 91, 95).

13 North (1981, p. 130).

14 North (1981, p. 131), see also Ogilvie (2007, p. 663), Ankarloo (2002, p. 25); Milonakis and Fine (2007, p. 47).

15 North (1979, p. 257); (1992, p. 27).

16 North (1981, pp. 25, 37); (1989, p. 1321).

17 North (1990a, p. 50).
} 
political arrangements, in particular, to the enforcement of property rights. In his book The Rise of the Western World (1973), North acknowledged that had did not properly address the issue of enforcement, although property rights were the main focus of his argument. ${ }^{18}$ This explains why, in his recent work, he placed more emphasis on the notion of credible commitment. He argues that credible commitment, as reflected in gradual improvements in the enforcement of complex contractual arrangements, explains England's economic success. His concept of credible commitment derives mainly from his interpretation of England's Glorious Revolution of 1688, which enhanced the security of property rights, thus contributing to the country's successful economic development and to its eventual emergence as a leading world power. ${ }^{19}$

At the time of the Glorious Revolution, England, along with other countries in Europe, faced the characteristic problem of having to secure reliable and steady streams of revenue. Earlier in the century, the fiscal crisis provoked acrimonious political exchanges that eventually led to civil war and to the overthrow and then restoration of the monarchy. The Glorious Revolution brought this period of instability to an end through a redesign of fiscal and governmental institutions. According to North, the institutional settlement of 1688 had the following features: (1) it curtailed royal prerogatives, subordinating them to the common law; (2) it gave Parliament a dominant role in the area of taxation; (3) it created an independent judiciary; and (4), it reaffirmed and strengthened the protection of property rights. ${ }^{20}$ Two related factors contributed towards boosting the authority of this settlement. Firstly, the recent removal of the previous monarch, James II, sent a clear message to the serving monarchs, William and Mary, that the social forces represented in Parliament were ruthless and determined to achieve their goals. And secondly, the considerable powers retained by William and Mary provided Parliament with a strong incentive to honour its side of the bargain. England's success in establishing institutions is apparent when compared with the fate of France and Spain during the same period. While the political settlement of 1688 enabled England to thrive economically and politically, France was unable to do so. The victory of Parliament led to the establishment of the Bank of England and the creation of new financial instruments that reduced the costs of transacting, enhanced the security of property rights and opened the way to a financial revolution. ${ }^{21}$ In his General Economic History, Max Weber discusses the politics leading to the establishment of the Bank of England. He notes, with some surprise, that the Bank was established as a private corporation and remarks that this institutional form was more suitable to a republic than a monarchy. ${ }^{22} \mathrm{Had}$ Weber been aware of North's interpretation of the political consequences of the Glorious Revolution, he may have come to see that the legal form selected for the

\footnotetext{
18 North (1993, p. 12).

19 North (1990a, p. 139).

${ }^{20}$ North and Weingast (1989, p. 816).

21 North (1989, p. 1327).

22 Weber (1961 [1923], pp. 198/9, 208).
} 
Bank's institutional structure was a reflection of a significant transformation of the monarchy and political authority. ${ }^{23}$

While England successfully managed a viable political settlement, France was unable to develop durable mechanisms for resolving its fiscal crisis. Louis XIV resorted to temporary measures that proved ineffective and, as a consequence, by 1765 France, after losing its North American colonies, was on the verge of bankruptcy. ${ }^{24}$ Spain fared no better.

According to North, the root cause of Spain's relative decline and the ensuing three centuries of stagnation were caused by a centralized bureaucracy that hopelessly tried to control every aspect of the economy through an inordinate number of decrees and regulations. ${ }^{25}$ North extends his comparison between England and Spain to explain the different paths taken by their colonies in the Americas. While England's colonies in North America adopted inclusive political systems, modelled on England, the Spanish colonies in the rest of the continent, reproducing the political flaws of their mother country, became centralised states. ${ }^{26}$

North's interpretation of the Glorious Revolution, though widely praised, has been the subject of close scrutiny. The main issue raised concerns the accuracy of the credible commitment/property rights/economic growth nexus. In particular, critics examine two main issues: (1) North's interpretation of the effect of the Glorious Revolution on property rights; and, (2) the role he assigns to property rights in bringing about the Industrial Revolution.

Some observers question North's emphasis on the impact of the Glorious Revolution on property rights. Indeed, long before the Glorious Revolution the concept of property was invoked in England to distinguish the rights of kings from the rights of private individuals. ${ }^{27}$ Deirdre McCloskey notes that property rights had been respected in England for many centuries, dating back to the Magna Carta of 1215 . $^{28}$ While most critics agree that the Glorious Revolution brought about greater security to some property owners, such as state creditors, not all forms of property were equally secure. Indeed, as Martin Daunton notes, North's argument about the security of property rights does not take into account the massive transfer of land in Scotland from clans to powerful landlords, the displacement of Irish landlords by English settlers, or the restricted rights of peasants in England. ${ }^{29}$ Although, in general, property rights in land were protected from interference by third parties or by the government, land was expropriated for a variety of purposes, mostly connected with public utility projects such as canals, docks and water supplies. ${ }^{30}$ According to Julian Hoppitt, the extent of these expropriations seriously undermines

\footnotetext{
23 Pincus and Robinson (2014).

24 North and Thomas (1973, pp. 121-127); North and Weingast (1989, pp. 830-831).

25 North (1971, p. 123); North and Thomas (1973, pp. 127-131); North (1990a, pp. 113, 122); (1992, p. 21).

26 North (1990a, p. 110); (1989, pp. 1329-1330).

27 Plucknett (2010 [1956], p. 37).

28 McCloskey (2010, pp. 336-337, 343); Clark (1993, p. 875).

29 Daunton (2010, pp. 152, 155).

${ }^{30}$ Harris (2004, p. 229).
} 
North's thesis that property rights became more secure after the Glorious Revolution. He notes, however, that it was precisely the increase in the scale of expropriations that gave Parliament the required flexibility to take advantage of new economic opportunities. ${ }^{31}$ Thus, economic prosperity, when it came about, was not because of an increase in the security of property, but because of the enhanced authority and respect of Parliament. ${ }^{32}$ Indeed, a consequence of the Glorious Revolution was that it enhanced the government's capacity to raise taxes and, consequently, its capacity to wage war. The efficacy of the English tax system was due largely to political reforms that strengthened the power of Parliament. 'If the monarch and his ministers could control Parliament, they were sure of consent for their fiscal policies. The passage of a tax bill through Parliament, once achieved, was far more potent than a decree for new taxes of an absolutist monarch. ${ }^{33}$ But, as ever, the tax system produced inequality. Ron Harris explains that during the eighteenth century, tax contributions from people who were not represented in Parliament increased, and the revenue thus collected was used to finance the imperial-mercantile projects of those who were overrepresented in Parliament, including the landed, financial and commercial elites. ${ }^{34}$ In terms of state building and political development, the Glorious Revolution was undoubtedly a watershed since it strengthened the authority of government, making it more effective both in waging wars and in furthering economic opportunities. ${ }^{35}$ Indeed, as Daunton explains, it was not just through open economic competition that England improved its economic position. The government was closely involved in promoting economic success by capturing markets and territories. He cites, as prime examples, the Navigation Act that drove Dutch ship-owners out of the market and the protection of the English textile industry against imports of dyed cloth from India. ${ }^{36}$ Thus North's attempt to link the Glorious Revolution with more secure property rights appears to be an oversimplification.

The link that North makes between the enforcement of property rights and the advent of the Industrial Revolution has also been questioned. McCloskey argues that between 1688 and 1815, economic institutions in England did not change a great deal. The Industrial Revolution, in her view, had little to do with major institutional change because property and contract, the two main institution associated with sustained growth, were already in place. $^{37}$ Gregory Clark agrees, noting that between the Glorious Revolution and the Industrial Revolution there was virtually no institutional change that had a bearing on the incentive to innovate. ${ }^{38}$ Joel Mokyr makes a similar point, albeit more guarded. In his view, the claim that the enforcement of property rights gave England an advantage in the Industrial

\footnotetext{
31 Hoppitt (2011, pp. 94-95).

32 Hoppitt (2011, p. 93); see also, Richardson and Bogart (2008, p. 33); McCloskey (2010, p. 315).

33 Brewer (1988, p. 376).

34 Harris (2004, p. 226).

35 Ertman (1997, pp. 208-223).

36 Daunton (2010, p. 155).

37 McCloskey (2010, pp. 343, 354).

38 Clark (1993, p. 875).
} 
Revolution is exaggerated. Instead, he draws attention to the importance of informal institutions as the stimulus to technological progress, rather than, as North argues, the formal patent system. ${ }^{39}$ According to Mokyr, what mattered was the high level of trust prevailing in civil society, which made it easier for individuals to engage in transactions with strangers. ${ }^{40}$ While these authors acknowledge the importance of secure property rights as a factor in explaining economic growth, they take issue with North's suggestion that there was a causal relationship between property rights, scientific innovation and the Industrial Revolution. ${ }^{41}$ Indeed, some argue that the causation line runs in the opposite direction: that it was the emergence of new technologies that generated demand for property rights, and that this led to the adjustment of property rights, which, in turn, facilitated further technological innovation. From this perspective, property rights are a consequence not the cause of technical change. ${ }^{42}$

\subsection{Credible Commitment, Property Rights and Economic Growth}

North makes a close link between the notions of secure property rights and credible commitment. Property rights are said to be secure when the state is able to make a credible commitment that it will respect them. The settlement associated with the Glorious Revolution is an example of an historical event that created conditions for the emergence of social and political trust, thus making credible commitment possible. In wider political terms, credible commitment is a promise by the sovereign to exercise its powers in accordance with predetermined rules or with rules fashioned by the parties as they work out an understanding to accommodate their respective interests. In this sense, credible commitment can be regarded as equivalent to the notions of constitutionalism or rule of law. Yet, the notion of credible commitment, as used by North, is not a normative concept, but more akin to the notion of limited government. In fact, one of the main consequences of the Glorious Revolution was to limit the powers of the monarchy. Yet, if North does not purport to extract from the Glorious Revolution a normative model, what does his analysis offer? One possibility, as David Stasavage suggests, is that the Glorious Revolution can be seen as providing a model whereby the main players - the King and Parliament - could trust each other because they had a veto over each other's actions: the King retained some of his prerogatives while Parliament could block additional sources of revenue. In his view, however, veto points, either single or multiple, are neither a necessary nor a sufficient condition for commitment. In his view, credible commitment ultimately depends on the way politics are structured. In particular, it depends on the identity of the groups who control the veto points and on the possibility of establishing cross-issue coalitions. These factors, he argues, are as important as the existence of limited government. ${ }^{43}$

\footnotetext{
39 North (1981, pp. 164-165).

40 Mokyr (2009, p. 352); (2005, pp. 287-289); see also Crafts (2010).

41 Engerman and Sokoloff (2005, p. 664).

42 Lipsey et al. (2005, p. 261); Demsetz (2000, pp. 78-79).

43 Stasavage (2002, p. 184).
} 
In England after 1688, as Stasavage explains, creditors were well represented in Parliament and were thus in a position to ensure that their interests were protected. But he also notes that the government did not consistently fulfil its commitment towards it creditors. ${ }^{44}$ A case in point was the South Sea Bubble of 1719-1720. Hoppitt describes the events leading to the Bubble as 'an attempt to privatize the national debt, sanctioned by act of parliament, and further legitimated by personal financial backing from many members of the court and parliament'. ${ }^{45}$ The shares in the South Sea Company subsequently collapsed, causing investors - former creditors of the state - to endure severe financial losses. $^{46}$

North's account of the South Sea scheme describes the event as a case of refinancing and does not mention the involvement of the government in the exchange of public debt into equity. He also appears to place the blame on the Company and fails to connect this event to his notion of credible commitment. ${ }^{47}$ The foregoing suggests that the meaning of credible commitment is not easy to grasp. If seen as a non-normative model, it is far too general to be useful. After all, even inefficient property rights are based on some form of credible commitment. Otherwise, they would either never come into existence or would last only for a very short time. Besides, criminal organizations, such as the mafia, are also based upon agreements to cooperate that, in formal terms, are no different from North's notion of credible commitment.

The notion of credible commitment has not captured the imagination of development economists. Parnab Bardhan, for example, argues that credible commitment is neither necessary nor sufficient for economic growth. The evidence of the few success stories among non-Western countries such as Japan of the Meji restoration, Korea and Taiwan in the 1960s and contemporary China confirms this. As for sufficiency, many of the constraints on economic development cannot be overcome merely by a commitment to limited government. ${ }^{48}$ Underlying Bardhan's argument is a more fundamental critique, which is that North's theory offers an oversimplified account of the Glorious Revolution and the Industrial Revolution. Indeed, the claim here is that by focusing largely on property rights, North's theory ignores non-economic factors - such as technological development, educational levels, resource endowment and geography - that have a bearing on the way society and individuals engage in economic activity. ${ }^{49}$ Because of the excessive emphasis that North places on institutions, some critics describe his interpretation as a form of institutional determinism. ${ }^{50}$ Other critics simply point out that the weakness of his theory is that, while secure systems of property rights are, undoubtedly, important

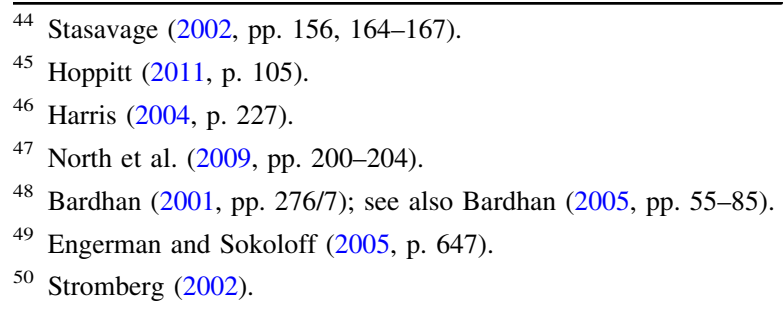


for economic growth, non-institutional factors also play a critical role in explaining growth and economic change. ${ }^{51}$

According to North, the essence of property is the right to exclude. ${ }^{52}$ This notion has been criticised as legalistic and oblivious to the fact that property rights are social relations. Rosa Congost and other scholars argue that North's legalistic notion of property forecloses a wider analysis of property rights from socio-economic perspectives such as social inequality and income distribution. ${ }^{53}$ Ha-Joon Chang notes that North's legalistic scheme does not fit all forms of property. The Chinese town and village enterprise (TVE) is a case a point. Under the TVE system, formal ownership is vested in local towns or villages, but the enterprise is run as if privately owned. ${ }^{54}$ The regulation of common-pool resources offers another illustration of property-right systems that is not easy to reconcile with North's narrow concept of property. $^{55}$

While North's definition of property is seen by many as excessively formal, his economic approach to it is far from formalistic. Indeed, he firmly links his concept of property to economic efficiency and defines efficient property as property capable of generating sustained economic growth. ${ }^{56}$ Efficient property rights are worthy of protection, while inefficient rights, such as those created by the high tariff barriers or by selectively generous tax concessions, are not. It is interesting to note that North's concept of efficient property may explain his alleged misinterpretations of English history. Indeed Daunton's and Hoppitt's assessments of North's views on property rights focus precisely on the failure to afford equal protection to all forms of property. Indeed, in seventeenth-century Britain, only efficient property rights were secure while property rights of the clans in Scotland or landowners in Ireland were no more secure than the rights of marginal groups in some developing countries today. According to Terra Lawson-Remer, such exclusive concern with efficient property rights explains why the only rights that seem worthy of protection in developing countries are the rights of foreign investors, while the property and other rights of the poor are consistently violated. ${ }^{57}$ Today, the efficiency perspective on property rights is reflected in contemporary governance rankings that measure the protection of property rights exclusively in terms of foreign investors' perception of the risk of expropriation. ${ }^{58}$

North's commitment to efficient property rights does not add precision to his analysis. Indeed, as Dani Rodrik and his associates argue, acknowledging that property rights are important does not tell us the form they should take because institutional arrangements are context specific. Without an analysis of the context,

\footnotetext{
51 Demsetz (2008, pp. 65-82).

52 North (1979, p. 250); (1981, p. 21); (1984, p. 208); (1990a, p. 33).

53 Congost (2003, pp. 74, 78); Milonakis and Fine (2007, p. 47).

54 Chang (2011, p. 8); Tian (2000); Zhang (2008).

55 Ostrom (2005, 1990); Bromley (2009, p. 21); (1989, p. 868).

56 North (1979, p. 251).

57 Lawson-Remer (2013, pp. 148, 151).

58 Przeworski (2004, p. 173).
} 
the call for protection of property rights is of little value. ${ }^{59}$ Thus, North's conception of secure property rights is narrow because it does not apply to every form of property. It is also worth noting that secure property rights tend to have a destabilizing impact because they are often associated with technical and economic progress, which, in turn, generates new sources of conflict, which again calls into question the security of property rights. ${ }^{60}$ Against this background it is difficult to disagree with Adam Przeworski's conclusion that the concept of secure property rights is a muddle. ${ }^{61}$

There is little doubt that North's interpretation of English and European history is as controversial as it is inspiring. It would, of course, be surprising if there was a consensus view on the interpretation of such momentous events as the Glorious Revolution and the Industrial Revolution. ${ }^{62}$ My main concern here is to ascertain the extent to which his interpretation of English and European history offers helpful perspectives for understanding the predicament of countries that, in North's terminology, have so far failed to develop efficient property rights. North acknowledges that England's historical trajectory cannot be replicated, but argues, nonetheless, that it reflects a 'fundamental tendency of economies in the western world'. ${ }^{63}$ In a more recent publication, he extended his analysis to show that the history of the USA and France also illustrate this fundamental tendency. ${ }^{64}$ Ultimately, however, North's focus on credible commitment and property rights overlooks that political and economic development are multifaceted processes. As Irma Adelman explains, identifying the nature and causes of economic growth and development requires a broad focus. The single factor, property-rights approach does not take into account the complex historical process underlying growth and development in different contexts. ${ }^{65}$ Gunnar Myrdal, who was passionately interested in the role of institutions in development, also rejects the focus on a single factor, calling instead for a comprehensive analysis of all social factors that have a bearing on growth. ${ }^{66}$ North probably did not disagree with the general proposition that a theory of institutional growth must be comprehensive, stretching its reach as wide as possible. Indeed, this may explain why, in recent years, he focused almost exclusively on devising a theory of institutions and economic growth. Whether North's theoretical work is as multifaceted or as comprehensive as Adelman and Myrdal would wish, is a question that can only be answered after considering his theoretical framework in greater detail.

\footnotetext{
59 Rodrik et al. (2004, pp. 157-158).

60 Toye (2008, p. 522).

61 Przeworski (2004, p. 173).

62 See, for example, Bendix (1978); Pincus (2009); Goldstone (2002).

63 North (1993).

64 North et al. (2009).

65 Adelman (2001, pp. 104/5); see also Lane (1979, pp. 82-90).

66 Myrdal (1978, p. 773).
} 


\section{Theory}

North's model of the ideal institutional framework is derived from his extensive research in economic history. Under this framework, property rights are protected, contracts are enforced and political authorities do not interfere with the choices made by economic entrepreneurs. This framework enables markets to operate efficiently over time. The time dimension is crucial since, as an economic historian, North was aware that, in order properly to evaluate institutions, it is essential to take into account their durability over time. An efficient institutional framework readily adapts to changing circumstances. ${ }^{67}$ Such a framework provides economic and political entrepreneurs with incentives that encourage decentralized decisionmaking, enabling society to maximize opportunities for resolving social problems and promoting successful economic change. ${ }^{68}$ Adaptively efficient institutions are thus a necessary condition for achieving successful economic change. Yet, the disparity between levels of economic growth between rich Western countries and poor countries in the rest of the world suggests that very few countries have managed to achieve efficient institutional frameworks. Why is this so? North's theory of institutions attempts to answer this question and offers a conceptual framework to explain economic growth and institutional development.

North's celebrated definition of institutions provided him with the starting point to develop his theory. He defined them as follows: 'Institutions are the rules of the game in a society, or, more formally, are the humanly devised constraints that shape human interaction. ${ }^{69}$ Institutions are established to reduce the obstacles arising from imperfect and asymmetrical information. The obstacles that institutions are meant to overcome are described as transaction costs. North distinguished two kinds of constraints: formal and informal. Together, these constraints comprise what he called the rules of the game. ${ }^{70}$

In this section I argue that, despite many positive and interesting features, North's theory is ambiguous and even contradictory owing to three related features: the pervasive and dominating influence of the principles of neoclassical economic theory; his exclusive focus on an end-point model based on successful Western economies; and, his reluctance to account for the role of organizations in the process of change.

Although North acknowledged that neoclassical economics has serious shortcomings, his own theory did not significantly depart from its principles and is thus susceptible to the same shortcomings. North's focus on Western economies as the end model for all states led him to regard any institutional framework that do not meet the ideal standard as deviant cases and therefore not meriting close investigation. His reluctance to offer a clear explanation about the role played by organizations in past and present institutional frameworks enabled him to leave

\footnotetext{
67 North (1994, p. 367).

68 North (1990a, p. 81).

69 North (1990a, p. 3).

${ }^{70}$ North (1990a, p. 4).
} 
social conflict out of his analysis and to ignore the complex nature of contemporary organizational structures.

This section begins with some observations about North's methodological premises. It then examines the origins of the so-called rules of the game, explains the distinction between formal and informal institutions and discusses his views on institutional change. It concludes by considering his attempt to explain the link between economic and political processes and the implications of the distinction between institutions and organizations. Throughout this section, I make several references to the link between North's notion of rules of the game and legal rules. However, I do not discuss law in detail as I do this in Sect. 4.

\subsection{Neoclassical Economics and Transaction Cost Analysis}

North's theory draws mainly from the principles of neoclassical economic theory. ${ }^{71}$ He regards the market and the price mechanism as a fundamental component of productive economies, is firmly committed to the view of individuals as utility maximizers and accepts the principle of methodological individualism. ${ }^{72}$ In philosophy, methodological individualism holds that the study of anything involves the study of individuals since in reality only individuals, or collection of individuals, are the subject of study. ${ }^{73}$ Under this view, collective entities are not real. The version of methodological individualism, accepted by most economists, is generally consistent with the view put forward by Joseph Schumpeter in 1908: the individual is the basis for the study of economics, in particular for the study of the price system. ${ }^{74}$ Schumpeter, however, does not extend the application of methodological individualism beyond the operation of the price system. North, by contrast, employs methodological individualism to the study of political and other social processes, as evidenced by his comprehensive approach to transaction costs, which I discuss in more detail below. For the moment, it is important to note that North adheres to the view that institutions are the product of intentional human action and are not predetermined by economic or any other logic.

North's agreement with the basic principles of neoclassical economics is, however, subject to an important qualification. In his view, neoclassical theory is unable to account for economic growth since it is only concerned with the operation of markets, not with the way markets develop overtime. ${ }^{75}$ As a consequence, it ignores the role of institutions, regarding growth exclusively as a function of the size of the population and the rate of savings. ${ }^{76}$ Hence, neoclassical theory only explains economic performance at a particular time, but is unable to explain dynamic change. ${ }^{77}$ Nevertheless, North's intention is not to replace neoclassical

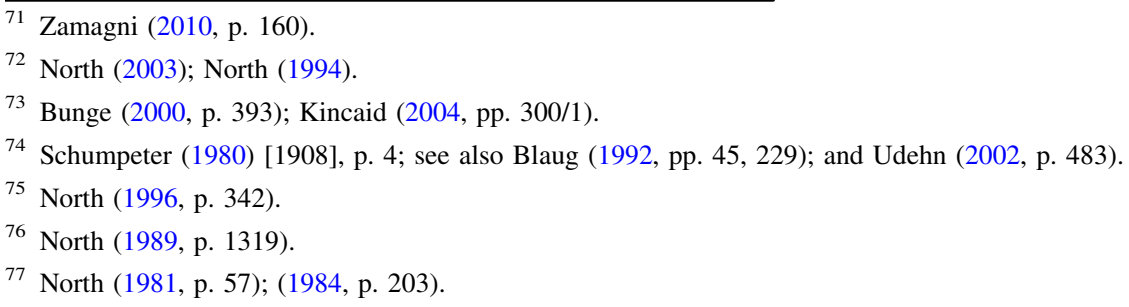


theory, but merely to improve its capacity to explain change over time. His main departure from orthodox economic theory is in his rejection of the rationality assumption relating to economic agents. According to neoclassical theory, market players repeatedly face the same choices and their preferences remain stable. As a consequence, players are capable of maximizing their preferences, and market outcomes reflect a stable and efficient equilibrium. Although neoclassical theory acknowledges that players might have incorrect information, it asserts that the competitive process provides them with feedback, which enables them to take rational decisions and pursue their maximizing objectives. Neoclassical theory, according to North, can afford such unrealistic assumption about individual behaviour because it takes institutions for granted. ${ }^{78}$ Since institutions play a critical role in determining the choices individuals make, economic analysis cannot afford to take institutions for granted. Thus, in order to bring institutions into his analysis North proposes that the rationality assumption should be loosened, though not dropped. In the real world, according to North, individuals do not face repetitive choices, their access to information is generally inadequate and their ability to process information is often blurred by their mental models. As a consequence, the competitive process, without the support of adequate institutions, cannot by itself generate suitable conditions to enable market players to adjust their preferences and decisions to the environment. ${ }^{79}$ Once it is accepted that markets do not yield efficient outcomes, the study of institutions becomes an essential component of any research project interested in explaining the origin of markets, their performance over time and the mechanisms that generate self-sustaining growth.

North's conceptualization of institution also relies on an expanded interpretation of Ronald Coase's transaction cost analysis. That North should embrace transaction cost analysis is unsurprising because the main point that Coase sought to emphasize was that market transactions could not be properly understood without taking into account institutions. Coase's transaction cost analysis is so widely accepted that it seems almost self-evident. ${ }^{80}$ Coase noted that in a world of zero transaction costs the initial allocation of a property right is a matter of indifference because the market will eventually assign it to the most valued user. Yet, since a zero transaction cost world is merely a hypothesis, what Coase sought to highlight was that institutions play a crucial role in facilitating, or obstructing, market transactions. Coase does not offer a detailed analysis of market supporting institutions, but notes that in the real world - a world of positive transaction costs - the role of legal systems is critically important. ${ }^{81}$ Despite the enormous influence of his work, in 1991 Coase complained that his followers had failed to grasp his main objective, which was to encourage others to study transactions in the real world, rather than focusing on building unrealistic models of market exchange: 'The time has surely gone in which economists could analyze in great detail two individuals exchanging nuts for berries on the edge of the forest and then feel that their analysis of the

\footnotetext{
78 North (1990a, p. 19); (1981, pp. 42-43).

79 North (1990a, p. 24); see also North (1981, pp. 1-7).

${ }^{80}$ Coase $(1937,1960)$.

81 Medema (1999, 2011).
} 
process of exchange was complete, illuminating though this analysis may be in certain respects.' ${ }^{2}$

Coase's transaction cost analysis is applied by Oliver Williamson and Douglass North, both leading figures within New Institutional Economics. Williamson's approach, also known as transaction costs economics, is concerned with alternative forms of governance as means of overcoming costs brought about by the incomplete nature of contracting. ${ }^{83}$ North, for his part, developed Coase's transaction cost analysis in a more ambitious direction. Not only does he apply transaction cost analysis to examine costs directly associated with market transactions, but extends it to include society as a whole. Thus, North's broad conception of transaction costs includes trading costs from the transfer of property rights in the market as well as the costs incurred in running and operating economic and political systems. ${ }^{84} \mathrm{He}$ defines transaction costs as 'the costs of specifying and enforcing the contracts that underlie exchange and therefore comprise all the costs of political and economic organization that permit economies to capture the gains from trade' ${ }^{85}$ This broad approach to transaction costs enables him to interpret the past, trace the evolution of institutions and assess the relative merits of institutional arrangements regardless of whether they are economic or political. ${ }^{86}$ Transaction cost analysis thus provides North with a powerful instrument to explore non-economic issues without using concepts from other disciplines. North's confidence in the suitability of transaction cost analysis to explain social phenomena across cultures and time is forcefully expressed in an article on Karl Polanyi. In this article, he addresses Polanyi's argument that modern economics concepts should not be used to explain pre-market societies. He rejects this view, arguing that transaction cost analysis 'is a promising analytical framework to explore non-market forms of economic organization' ${ }^{87}$ His reasoning is that all societies employ some mechanism to assign rights and allocate benefits even though in some societies property rights in the Western sense may not exist. Therefore, since wealth maximization is a universal principle, it can be assumed that the same reason (transaction costs) that prompts economic actors to choose substitutes to the market can also be used to explain the rationale of economic institutions in pre-capitalist societies. ${ }^{88}$ Some have strongly criticised North's broad conception of transaction costs. ${ }^{89}$ Milonakis and Fine describe his broad conception as an attempt that purports to explain almost anything while distorting historical events. ${ }^{90}$ Such a broad approach also oversimplifies the analysis

\footnotetext{
82 Coase (1994, p. 12).

83 Williamson (1985, 1995 and 2005); for a comparison of the theoretical differences between Williamson and North see, Hirsch and Lousbury (1996, p. 879).

84 North (1992, p. 6).

85 North (1984, p. 203).

86 Allen (2000, pp. 899, 902); Schlag (1989).

87 North (1977, p. 709).

88 North (1977, p. 711).

89 Milonakis and Fine (2007), Ankarloo (2002).

90 Milonakis and Fine (2007, p. 52); see also Ankarloo (2002).
} 
of social processes because it turns the concept of efficient markets into a gold standard for the analysis of non-economic factors in society. ${ }^{91}$

North applies transaction cost analysis to study issues that are not generally regarded as appropriate for economic analysis. Interestingly, the use of economic analysis to explain non-economic issues was also considered by Schumpeter. By contrast to North, however, his approach was restrained. In his view, economics should respect the sphere of competence of other disciplines because its proper role is to explain economic factors. He did not advocate extending economic analysis to the study of non-economic factors.

When we succeed in finding a definite causal relation between two phenomena, our problem is solved if the one which plays the 'causal' role is non-economic. We have then accomplished what we, as economists, are capable of in the case in question, and we must give place to other disciplines. If, on the other hand, the causal factor is itself economic in nature, we must continue our explanatory efforts until we ground upon a non-economic bottom. ${ }^{92}$

North does not heed Schumpeter's advice, relying instead on economic methodology to analyse and explain economic and non-economic factors. This approach enables him to exclude from his framework relevant research from other social sciences, especially those that provide insights into social conflict and social structure. Having excluded other social science disciplines, he resorts to psychological explanations. As Udehn explains,

[T] he rule guiding this form of methodological individualism says that no economic explanation is considered successful until all exogenous variables have been reduced to psychological states of individuals and natural constraints. Social institutions may appear in the models of neoclassical economics, but only as endogenous variables. ${ }^{93}$

Fortunately, North does not apply this methodology consistently. His discussion on the origins of rules, the nature of institutional change and the link between political and economic processes forces him partly to depart from methodological individualism. ${ }^{94}$ In the end, however, his methodology becomes a straightjacket and is one of the main reasons that explain the shortcomings of his theory. ${ }^{95}$

\subsection{Rules of the Game}

According to North, 'institutions are created by individuals - evolve and are altered by individuals' ${ }^{96}$ He distinguishes institutions from organizations. Institutions are

\footnotetext{
91 Nelson (2002); Lane (1979, p. 84).

92 Schumpeter (1934, pp. 4-5).

93 Udehn (2002, p. 483).

94 Rutherford (1989, p. 303).

95 Field (1981, p. 178); (2006).

96 North (1990a, p. 5).
} 
the rules of the game while organizations along with individuals are players in the game. This distinction, however, is not as clear as it seems. Indeed, North acknowledges that, in some cases, which he does not specify, organizations are also institutions since they provide a structure for human interaction. ${ }^{97} \mathrm{He}$ insists, however, that, although organizations may be regarded as institutions, it is the individual, who, as a member of an organization, makes choices leading to the establishment or change of institutions. ${ }^{98}$ I will return to North's distinction between institutions and organizations, but it is sufficient here to note that, in his view, individuals are the originators of institutions, even though, occasionally, they are so as members of organizations.

North does not restrict the concept of institution to economic institutions so his theory applies to any set of rules that govern social interaction. It is not immediately clear whether North's rules of the game are merely heuristic devices to help us make sense of economic processes, constitute the activity itself or are the cause that determines the activity of individuals. He does not explicitly address these questions. He simply states that institutions set the rules of the game and players individuals and organizations - play the game in accordance with these rules.

While North does not offer a clear explanation about the nature of the rules of the game, he addresses this question, albeit indirectly, in his discussion on the origins of formal and informal rules. He describes formal rules as a set of rules within a normative hierarchy similar to those found in modern legal systems. His account about the origins of informal rules suggests that they originate in the mind of individuals, but are a reflection of prevailing cultural conditions. Thus, not surprisingly, some observers describe his approach as culturalist. ${ }^{99}$ Others argue that his theory of institution is close to the Old Economic Institutionalism because it relies on social habits and tradition as sources of institutions. ${ }^{100}$ To clarify these points it is necessary to look closer look at North's conception of formal and informal institutions.

Formal institutions, according to North, have a hierarchical structure similar to legal norms, which runs from the constitution to statute and common law, to bylaws, and contracts. 'The rules descend from polities to property rights to individual contracts. ${ }^{101}$ Contracts reflect the incentives generated by the prevailing structure of property rights. In other words, the opportunity set of economic actors is derived from the prevailing structure of property rights. ${ }^{102}$ 'The existing structure of rights (and the character of their enforcement) defines the existing wealth-maximization opportunities of the players, which can be realized by forming either economic or political exchanges. ${ }^{103}$ North's description of formal institutions seems to equate this type of institution with officially enacted legal rules. While this characterisation

\footnotetext{
97 North (1990a, p. 6).

98 North (2005a, p. 63).

99 Khalil (2012).

${ }^{100}$ Rutherford (1994, pp. 43-50, 162-165).

101 North (1990a, p. 52).

102 North (1990a, p. 52).

${ }^{103}$ North (1990a, p. 47).
} 
might seem unproblematic, especially for lawyers, it is not easy to reconcile with his proposition that institutions are largely made and changed by individuals. Indeed, his account of formal institutions entails a top-down conception of institutions as imposed on individuals by external forces and hence is inconsistent with his view that individuals are originators of institutions. This problem is also manifest when he discusses the role of elites in framing social order and shaping the link between economic and political processes.

Informal institutions or informal rules play an important role in North's theory. In Institutions, Institutional Change and Economic Performance he acknowledges the importance of informal constraints, including conventions, customs and codes of behaviour, but does not fully explain how informal rules originate. He simply states that subjective perceptions are both culturally derived and modified by experience. He does, however, argue that changes in relative prices have the effect of gradually altering cultural norms and ideology. ${ }^{104}$ Fifteen years later, relying on principles of cognitive science, he presented a more refined interpretation of informal constraints, linking them firmly to individuals' shared mental models and belief systems. ${ }^{105}$ Informal constraints, according to North, originate in the mind and can be traced back to cultural values. As a consequence, any attempt to bring about economic or political change will either be facilitated or obstructed by prevailing cultural values. ${ }^{106}$ Indeed, North repeatedly noted that the reason why so many plans to reform the economy fail is because reformers focus on changing the formal rules of the game, but disregard informal constraints. Those who want to bring about institutional change must ensure that the informal rules of society are consistent with the outcomes that the formal rules seek to achieve. ${ }^{107}$ Although North did not claim to have a fully developed theory about cultural beliefs or ideology, in his recent work he focused on the learning process as a means of understanding how particular belief systems emerge. ${ }^{108}$ This process takes place in the mind of the individual, but its cumulative effect has a societal impact beyond the control of any single individual. ${ }^{109}$ Thus, choices made by individuals are shaped by their mental models embedded in widely shared belief systems, which, in turn, are the product of repetitive feedback from the social environment. North explains the link between mental models, belief systems and institutions as follows: mental models are the predictions the mind makes about the environment; these models are revised or confirmed depending on the feedback individuals get from experience; mental models that are repeatedly validated become beliefs; and finally, when beliefs are widely shared they become belief systems. ${ }^{110}$ Thus, institutions are 'nothing more than shared mental models or shared solutions to recurrent problems of social

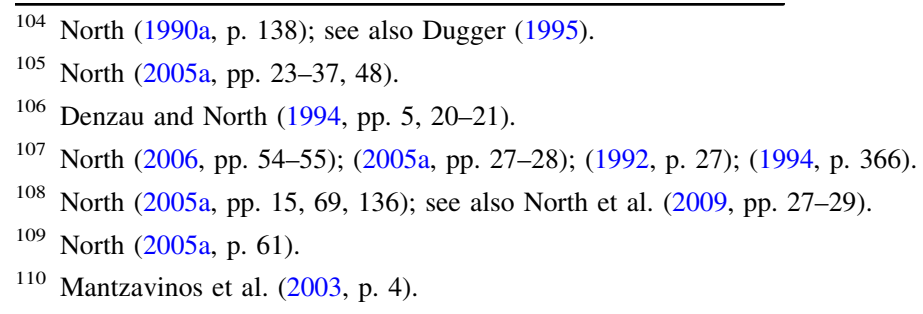


interaction. Only because institutions are anchored in people's minds do they ever become behaviorally relevant'. ${ }^{111}$

The influence of culture and informal rules is pervasive, according to North. Indeed, in his view, the reason why, throughout history, most societies have failed to grow is because they are trapped in institutional frameworks that do not create incentives to develop impersonal exchange. As a consequence, they are unable to benefit from the division of labour. ${ }^{112}$ His views about the importance of culture and belief systems in the process of institutional change are closely linked to his views on path dependency. He regards the relationship between belief systems and institutions as intimate. Belief systems are the internal representation of reality, while institutions are structures that individuals impose on reality. ${ }^{113}$ As a consequence, successful institutional change requires changing collective belief systems. ${ }^{114}$ Since bringing about this type of change is difficult, institutions tend to endure overtime and change slowly. The obstinate durability of institutions is what he calls path dependence. ${ }^{115}$ Path dependence is relevant to understanding how informal institutions originate and evolve. The dilemma is, of course, whether reformers wishing to establish efficient institutions should engage in a campaign to shift cultural values from collectivist ideologies towards individualistic approaches. North shies away from this task because 'the degree to which such cultural heritage is 'malleable' via deliberate modification is still very imperfectly understood. At any time it imposes severe constraints on the ability to effectuate change'. ${ }^{116}$ In the end, he advises would- be reformers not to ignore cultural heritage.

Among informal institutions North includes superstitions, religions, myths, prejudices and fundamentalist creeds, which he describes as a reflection of our universal addiction to non-rational explanations of reality. ${ }^{117}$ This extensive list presumably also includes ideology, although by 2005 he had largely abandoned the use of this concept. ${ }^{118}$ Scientific theories are rational explanations, but not all scientific theories meet North's rationality test. For example, North regarded the economic theories developed by the UN Economic Commission for Latin America and the Caribbean (ECLAC) in the 1950s and 1960s as examples of erroneous mental constructs that obstructed the path towards economic growth. In his view, ECLAC economists' mistaken attempt to attribute the plight of Latin American economies to the deterioration of terms of trade was a rationalization that had the effect of reinforcing the prevailing inefficient institutional framework. ${ }^{119}$ This astonishing critique reflects a level of insularity that is rare in North's scholarship. His views on religious and irrational beliefs are interesting, but not fully developed.

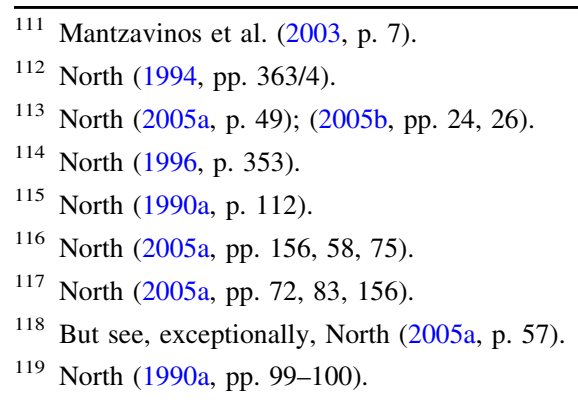


Although he refers to Max Weber's celebrated book The Protestant Ethic and the Spirit of Capitalism, he refrained from taking sides in the longstanding debate over Weber's thesis on Calvinism and capitalism. He noted, however, that along with Protestantism, the Catholic counter-reformation may have contributed to promoting market-friendly behaviour. ${ }^{120}$ His views on Islam were less cautious. He attributed the failure of Muslim countries to follow the dynamic scientific changes of the West to culture. ${ }^{121}$

North's main concern, however, was to identify cultural conditions (informal institutions) that foster impersonal market exchange. Drawing on Avner Greif's work, he compares the approach of Maghribi and Genoese traders in the eleventh century.

Maghribi traders were a cohesive community who developed a range of informal mechanisms that enabled them to apply sound and effective trading practices. When trade expanded and became impersonal their practices proved inadequate. By contrast, Genoese traders, who were individualistic, developed bilateral legal mechanisms that enabled them successfully to carry out impersonal trade. ${ }^{122}$ In the context of North's views on informal institutions, it is relevant to ask how Genoese traders acquired their individualistic values. Was it social interaction? If so, why did Maghribi traders involved in comparable activities, fail to develop similar values? If the Genoese traders did not develop individualistic values through their trading practices, how did they acquire them? North does not address this issue, but refers, approvingly, to Alan McFarlane's study on the origins of individualism in England. ${ }^{123}$ McFarlane traces its origins to the thirteenth century, long before market relations became dominant. If his interpretation is correct, then the obvious question is how did English peasants acquire their individualism? A similar question could be asked about the ideology of the traders from the Maghreb. If they were engaged in activities similar to those of the Genoese traders, why were they unable to discard their collectivist ideology? Interestingly, Barrington Moore, in his magisterial Social Origins of Dictatorship and Democracy, poses a similar question in relation to Japanese merchants during the Tokugawa period. Why did Japanese merchants during this period not oppose traditional values, thus failing to develop an outlook similar to that of their counterparts in the West? Moore rejects, as question begging, explanations that focus on the psychological traits of Japanese merchants or their value system. Instead, he argues that the answer can be found in history, examining factors such as the country's isolation, the long political dominance of the warrior class and the merchants' long association with them. ${ }^{124}$ North's approach is different. He does not carry out this type of inquiry. Instead, he attributes the behaviour of the Genoese and Maghribi traders to their mental maps. Nevertheless, his views here reveal considerable ambivalence, as reflected in his

\footnotetext{
${ }^{120}$ North (2005a, p. 135).

121 North (2005a, p. 44).

122 North (2005a, p. 136); Greif (2006, p. 269); for a critique of Greif's interpretation see Edwards and Ogilvie (2012); for Greif's response see Greif (2012).

123 McFarlane (1978); for reviews of this work see Pocock (1980); Hilton (1980).

124 Moore (1966, p. 240).
} 
brief comments on a study by Jean-Philippe Platteau and Yujiro Hayami, which discusses the origins of social norms in African and Asian communities. ${ }^{125}$ In their work, Platteau and Hayami attribute the origins of these norms to structural economic and demographic factors rather than to belief systems. While North acknowledges that their argument is not unfounded, he avoids further discussion claiming that "we are some distance from a definitive understanding of the source and implications of diverse cultural backgrounds'. ${ }^{126}$ Ultimately, he refuses to consider specific historical conditions as possible explanations for the diverse behaviour of different social groups. Neither does he regard social interaction, even market interaction, as relevant to the generation of cultural values.

North's notion of culture poses a dilemma for his interpretation of economic and political change. Indeed, as he constantly reminds his readers, while formal rules can be changed by the stroke of the pen, informal rules are not easy to change. ${ }^{127}$ This is why the same rules applied in different societies often lead to dissimilar outcomes, while different rules often yield the same result. ${ }^{128}$ The role of informal constraints in understanding the process of change is crucial. Indeed, it would seem that, provided that informal rules favour market outcomes, economic growth will take place, even when prevailing formal rules may not be market-friendly. ${ }^{129}$ Thus, while the efficacy of formal rules is dependent on favourable informal constraints, the same is not necessarily true for informal rules. This is why North argues that governments interested in improving economic performance must ensure that belief systems in their respective societies favour the enforcement of efficient property rights. 'Institutions and belief systems must change for successful reform, since it's the mental modes of the actors that will shape choices. ${ }^{130} \mathrm{He}$ does not, however, explain how this change of beliefs should come about, other than saying that it took the West a long time to bring informal rules in line with the substantive demands of the market. ${ }^{131}$ Nonetheless, he is convinced that the collectivist orientation prevailing in some non-Western countries accounts for their failure to develop sound economic systems. ${ }^{132}$

North is undoubtedly correct in pointing out that people's beliefs about institutions are important. When collective beliefs are in accord with the prevailing institutional framework, the legitimacy of institutions is enhanced. Yet his analysis of informal institutions does not explain how people, as a group, acquire their beliefs.

Undoubtedly many collective beliefs are acquired over time and fall within the category of traditions that are part of a group's cultural heritage. Yet, many beliefs, in the realm of politics, religion and commerce, are purposely created by powerful

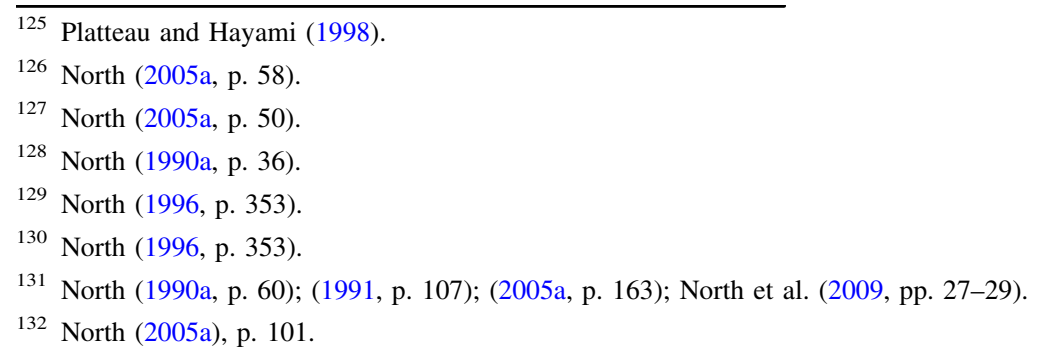


groups. Although North refers to ideology he does not consider how ideological manipulation might be related to people's belief systems. ${ }^{133}$ Indeed, while it is true that not all beliefs and practices are 'amenable to deliberate human manipulation', ${ }^{134}$ not all value systems and norms grow spontaneously in communities. As Barrington Moore explains,

[t]o maintain and transmit a value system, human beings are punched, bullied, sent to jail, thrown into concentration camps, cajoled, bribed, made into heroes, encouraged to read newspapers, stood up against a wall and shot, and sometimes even taught sociology. To speak of cultural inertia is to overlook the concrete interests and privileges that are served by indoctrination, education, and the entire complicated process of transmitting culture from one generation to the next. ${ }^{135}$

While North might have shared Moore's views, his analysis of informal institutions suggests that they are rigid and almost impossible to change. Yet, his views on ideology were ambivalent. His concept of ideology is broad and undistinguishable from cultural factors. It includes the individual's subjective perceptions, as well as religious and political ideology, which in 1990 he described as organized ideologies. ${ }^{136}$ In this sense he acknowledges that ideology is an external force that plays a role in changing behaviour. ${ }^{137} \mathrm{He}$ is also confident that the impact of organized ideology does not last forever. Indeed, in relation to the economic and political liberalization that took place in Eastern Europe, he notes that socialist ideology, despite its enormous power, was swiftly dislodged by individuals' proclivity to maximize their wealth. ${ }^{138}$ Despite his ambivalence, what emerges from his analysis is that a critical source of informal institutions is the community or as he describes it, 'the cultural transmission of values'. ${ }^{139}$ Thus, he effectively removes the individual as the primary source of informal institutions. ${ }^{140}$ Informal institutions are not the product of isolated entrepreneurs who strive to maximize their utility. On the contrary, informal institutions emerge spontaneously from 'a process of innovation and imitation that takes place in a social group that is learning collectively. Individuals respecting conventions, following moral rules, and adopting social norms cause (as an unintended outcome of their action) the emergence of social order'. ${ }^{141}$ North did acknowledge Friedrich Hayek's influence in the development of this evolutionary conception of informal institutions. ${ }^{142}$

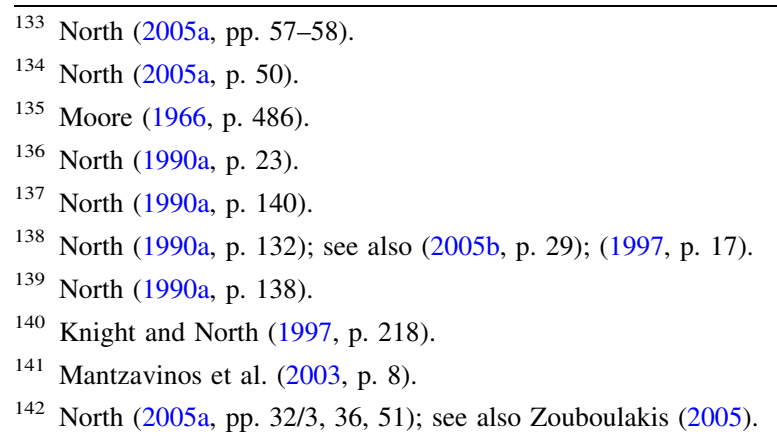




\subsection{Institutional Change}

North's conceptual framework envisages institutional change, but change, when it happens, is incremental and unlikely to shift in the direction of adaptive efficiency. Indeed, his ideal end point for institutions seems beyond the reach of most countries. $\mathrm{He}$ attributes this to unfavourable cultural and political conditions prevailing in countries outside the small magic circle of advanced industrialized economies. This unpromising situation explains why, in 1990, North warned his readers that his theory 'provides no guarantee of a happy ending' ${ }^{143}$ This subsection explains the reasoning underlying his pessimism and considers whether it reflects an irredeemably flawed reality or exposes the shortcomings of his theory.

The main sources of institutional change are variations in relative prices and in players' tastes. Changes in relative prices include changes in the ratio of factor prices, in the cost of information and technology. Some changes are exogenous (for example, caused by the outbreak of a major epidemic) while some are endogenous (brought about by the internal dynamic of the economic process) and reflected in the maximizing efforts of economic actors. ${ }^{144}$ Institutions establish a structure of incentives that enable economic entrepreneurs to adjust while maximizing their utility. High returns for certain productive activities prompt economic actors to invest in them. Thus North states that '[I]f the highest return in an economy is to piracy we can expect that the organizations will invest in skills and knowledge that will make them better pirates. ${ }^{145}$ If his maximizing entrepreneurs do not focus on becoming better pirates it is because social norms, conditioned by changes in tastes, bring about institutional changes that outlaw piracy (or slavery and similar activities). Likewise, he attributes the abolition of slavery not to economic factors relating to efficiency or transaction costs, but to the emergence of norms that question the legitimacy of one person owning another. ${ }^{146}$ However, he does not explain the political, social or economic factors underlying the shift in moral preferences.

North's assessment of the role of individual entrepreneurs in the process of institutional change is not encouraging. He notes that, while changes in relative prices provide the lone entrepreneur with the incentive to seek institutional change, the likelihood of achieving success is limited. Imperfect markets, bounded rationality, path dependency and ideological prejudices are all factors that account for the frequency of inefficient outcomes. As a consequence, the entrepreneur is left with two unattractive choices: either to accept minor and unsatisfactory adjustments to the rules of the game or express dissatisfaction by refusing to comply with prevailing rules. But since the option of non-compliance is risky, most people prefer to wait for others to take the initiative. ${ }^{147}$ Thus, efficient outcomes - that is, market

\footnotetext{
143 North (1990a, p. 132).

144 North (1990a, p. 84).

145 North (2005a, p. 61).

146 North (1990a, p. 24).

147 North (1990a, pp. 86-90).
} 
outcomes that yield the lowest possible production and transactions costs - are elusive, while free-riding on the efforts of others seems to be the social norm. ${ }^{148}$

Efficient political outcomes are also elusive. Indeed, they are exceptional since political markets are even less perfect than economic markets. The most important function of rulers is to specify, enforce and protect property rights. But rulers are inclined to safeguard their narrow interests rather than achieve outcomes that further productive activities. ${ }^{149}$ Two main reasons explain their behaviour: (1) they face competitive constraints compelling them to establish property rights that benefit powerful groups in the polity; and, (2) they face transaction cost constraints because since enforcing an efficient system of property rights is costly they would not necessarily benefit from such a system in terms of revenue. As a consequence, rulers are inclined to grant monopoly rights rather than encourage competition. ${ }^{150}$ Under this view, rulers (or the state) are indispensable and inadequate: indispensable because they establish and specify property rights that facilitate market exchange; and inadequate because they consistently fail to design an ideal structure of rights. These factors explain why institutional change, when it occurs, is slow and rarely culminates with the establishment of efficient institutions. Thus, North's theory of institutional change leads to a deadlock. Economic processes do not yield efficient outcomes because entrepreneurs operate in imperfect markets and do not have the capacity or incentive to promote changes. Likewise, political entrepreneurs are also incapable of providing efficient solutions because they represent the interest of powerful groups who are generally satisfied with the prevailing structure of property rights and other political advantages. This unpromising situation explains why North warns his readers that his theory does not guarantee a happy ending.

\subsection{Political Development}

North rightly identifies the problem that leads his theory into a deadlock. It is the conceptualization of the link between economic and political processes. Accordingly, in his most recent book, Violence and Social Orders, he sets out to provide a systematic account of this link, focusing in particular on the way societies have handled the problem of violence. ${ }^{151}$ In the opening pages, he and his co-authors confidently state that, hitherto, social scientists have failed to understand the connection between the economy and the polity because they have not seriously studied the problem of violence. ${ }^{152}$ This bold evaluation of the contribution of social science to the study of political development is undoubtedly controversial. My task, however, is not to assess its validity, but to ascertain whether his new approach resolves the deadlock in his theory of institutions.

North divides social orders that have existed historically into three types: foraging orders, limited-access orders and open-access orders (hereafter OAOs).

\footnotetext{
148 North (2005a, p. 15); (1979, p. 258).

149 North (1981, p. 28).

150 North (1981, p. 28).

151 North et al. (2009).

152 North et al. (2009, p. xi).
} 
Foraging orders, no longer in existence, prevailed in hunter-gatherer societies. Limited-access orders, or natural states, have been around for more than ten thousand years. Open- access orders date back to the middle of the nineteenth century, and are associated with sustained political and economic development of the type that led to the establishment of successful market economies in Western Europe and North America. Today, only a minority of states fall within the OAO category - no more than 25 - and includes only $15 \%$ of the world population. ${ }^{153}$ The rest of the world lives in limited-access orders. OAOs are easy to identify as they follow closely the ideal features of liberal democracies in advanced market economies. OAOs have the following characteristic: (1) a widespread belief in inclusion and equality; (2) no entry restrictions to economic, political, religious, and educational activities; (3) support for the establishment of organizations designed to further these activities; (4) impersonal exchange; and, (5) impartial enforcement of the rule of law (ibid:114). A critical feature of OAOs is that they resolve the problem of violence by asserting democratic control over the military.

While it is easy to recognize the kind of political regime underlying North's description of OAOs, this is not the case with his description of natural states. His characterization of these states is not based on the features of any single country or group of countries. Instead, using OAOs as the ideal standard, he proceeds to identify the feature of countries that do not meet this standard. Thus, by contrast with OAOs, natural states have not fully resolved the control of violence and are therefore unable to guarantee auspicious conditions for productive trade and investment. Members of the dominant coalition in natural states have access to violence and grant each other special privileges to assets and valuable activities. Natural states remain stable, but only as long as the dominance of the ruling coalition is unchallenged. While natural states favour some forms of productive activities, they cannot guarantee secure property rights or orderly economic processes because they arbitrarily allocate political rights and economic privileges. Natural states do not fully control the sources of violence, and organizations established in these states tend not to survive beyond the life of their founders. Moreover, by contrast with OAOs, natural states restrict peoples' access to economic and political activities, do not treat them as equals, do not enforce the law impartially and do not establish conditions that promote impersonal market exchange.

North's description of natural states is too general to be helpful. It reads almost like a caricature of the political economic structures of developing countries. Indeed, the notion of natural state is so broad that countries as different as Argentina and Malawi, India and Sudan, or Malaysia and Myanmar, are all in the same group. Anticipating criticism North distinguishes three types of natural state: fragile, basic and mature.

Fragile are those that are on the verge of collapse and are unlikely to survive any threat of violence. Basic natural states have an organizational framework that defines the structure of the state and regulates relations among members of the dominant coalition. Mature natural states are more advanced and are capable of

153 North et al. (2009, p. xii). 
maintaining independent elite organizations. But, how do mature natural states become OAOs? North offers no clear answer. Instead, he identifies three conditions, described as doorstep conditions, which once in place might generate incentives towards establishing OAOs. They are: rule of law for elites; perpetually lived organizations in the public and private spheres and consolidated control over the military. ${ }^{154} \mathrm{He}$ defines rule of law for elites as the case where relations among members of the elite are governed by legal procedures partly protected by a judicial body. Perpetually lived organizations foster the existence of impersonal relationships and exchange, thus securing the inviolability of contracts and the protection of property rights. ${ }^{155}$ Consolidated control over the military requires an organization that is embedded within the structure of the state and controls all the military resources. ${ }^{156}$ North does not, however, explain why doorstep conditions emerge in some countries and not in others. Neither does he offer a satisfactory account about the transitions from mature state to open-access order. In his view, the transition begins when the elites transform their privileges into impersonal rights. Yet he does not explain what prompts them to make this concession. Instead he states that they do so when they 'perceive that their privileges will be more secure from intra-elite competition when those privileges are defined as commonly shared rights rather than personal prerogatives'. ${ }^{157}$ In any event, he points out that asking what prompts elites to give up their privileges is the wrong question and suggests an alternative question: 'Why do elites transform their unique and personal privileges into impersonal rights shared equally among elites?" ${ }^{158}$ The answer to this is that they do so when it is in their interest to do so. However, this answer does not address a more fundamental question: what prompts them to realise that they no longer need to cling on to their privileges? North does not address this question, finding it superfluous. He regards institutional change as a smooth process that happens when enlightened and self-interested elites realise that it is in their interest to transform their privileges into abstract rights. This interpretation seemingly resolves the question of the link between political and economic processes since the elites oversee and determine the timing of the institutional transition from natural states to OAOs. The difficulty, however, is that it fails to take into account that, throughout history, elites have consistently used force to defend and enhance their privileges. The history of countries classified as OAOs offers well-known illustrations of the diverse strategies employed by elites to protect their privileges. As noted earlier, North attributes the abolition of slavery to changes in moral preferences, not to political and social struggles. Likewise, the relatively recent struggle for civil rights in the United States is another case that shows that elites do not make political concessions merely because they are enlightened. North acknowledges, in passing, that the 1964 Civil Rights Act in the United States was preceded by violent

\footnotetext{
154 North et al. (2009, p. 151).

155 North et al. (2009, p. 152).

156 North et al. (2009, p. 153).

157 North et al. (2009, p. 190).

158 North et al. (2009, p. 25).
} 
confrontation. ${ }^{159}$ Yet, he does not regard this, or similar experiences in other countries, as contradicting his view that elites make concessions when it is in their interest to do so. In any event, most historians, and even lawyers, are fully aware that the extension of rights to subordinate classes in nineteenth-century Europe was not conflict-free nor was it the product of gracious concession by enlightened elites. $^{160}$

A point North failed to develop is related to the possibility of transplanting institutions modelled on OAOs regimes so as to speed up the process of change. In Sect. 4 (below), I explain that North was critical of development assistance projects that disregard the cultural heritage and political structures of recipient countries. This, he believed, was futile because social orders have their own logic that should not be disturbed. Indeed, institutions transplanted from outside will either fail to work or, worse, may disrupt the social order of natural states. Intriguingly, however, when he traced the history of the transition to OAOs of countries that he described as the first movers (England, France, Holland and the United States), he acknowledged that, elsewhere in the world, subsequent transitions achieved similar institutional outcomes regarding key institutions and the widespread extension of citizenship rights. He rejected the view that these similar outcomes can be explained as an incident of modernity. Yet, in characteristically eclectic style, he concluded that 'the first movers deliberately constructed social tools that supported more sophisticated organizations and made those tools available to all elites'. ${ }^{161}$ The notion that the first movers made their institutional tools widely available to elites elsewhere in the world might suggest that agencies promoting the establishment of similar institutions in developing countries are not necessarily following such an unreasonable policy. Unfortunately, North did not pursue this point.

\subsection{Institutions and Organizations}

North's distinction between social orders offers an academically interesting classification of regime types, but neither resolves the issue concerning the link between economic and political processes nor offers a persuasive alternative theory of political development. Also he fails to link, explicitly and systematically, his findings in Violence and Social Orders with his theoretical work. It could well be that this book was only a prolegomenon to future work. For the purpose of this paper, what needs to be examined is why did North fail properly to address the link between economic and political processes. To do this, it is necessary to discuss his approach to the following three related issues: the relationship between informal and formal institutions; the distinction between institutions and organizations; and the link between the behaviour of individuals and macro social processes. In brief, why is it that, in North's conceptualization, the lone entrepreneur is unable to have a wider societal impact? Why is s/he permanently blocked by selfish political

\footnotetext{
159 North et al. (2009, p. 120).

160 Bendix (1977 [1964], pp. 89-126).

161 North et al. (2009, p. 194).
} 
entrepreneurs? In other to answer these questions it is necessary to examine how North envisages the relationship between the individual and social institutions.

According to North, institutions are created and altered by individuals. However, he does not consistently adhere to the view that individuals are the sole originators of institutions. As noted above, informal institutions are not generated by the action of isolated individuals, but are the product of belief systems, developed and validated by cultural and community values. There is no doubt that North's insights into the relationship between culture and economic change are valuable. Nevertheless, his theory fails to explain how informal institutions are transformed into formal institutions. In the final paragraph of his 1990 book, Institutions, Institutional Change, and Economic Performance, he acknowledges that he failed to find an answer to this important issue. ${ }^{162}$ Nonetheless, did not revisit this question. Although he repeatedly observes that informal and formal institutions should be properly aligned to achieve positive outcomes, he does not consider how informal institutions become formal institutions. An explanation for this omission may be that while his conception of informal rules is largely psychological, his conception of formal rules is top down and legalistic. His description of formal rules is hard to distinguish from a lawyer's description of the hierarchy of rules in a modern legal system. Therefore, it is hardly surprising that he has been unable to link informal and formal institutions other than by warning that formal institutions should not ignore prevailing cultural constraints. In any event, North's top-down account of formal institutions overrides his fundamental premise that institutions are created by individuals. Legal rules, are created, interpreted and changed by organizations, not by lone individual entrepreneurs or selfish political operators. If this analysis is correct, why then does North fail to acknowledge that the rules of the game do not emerge spontaneously from the minds of individuals, but instead are artefacts created by organizations? Although he does not completely ignore this question, his response is incomplete and does not dispel the ambiguity in his theory.

One of the most confusing features of North's conceptualization is his distinction between institutions and organizations. This distinction is unclear, as has been noted by several scholars. ${ }^{163}$ Institutions, according to North, are the rules of the game, while organizations are players. Organizations consist of groups of individuals bound by a common purpose and are subject to the same rules as individuals. Yet, he admits that in some cases, which he does not identify, organizations can also be regarded as institutions, as they provide a structure for human interaction. ${ }^{164} \mathrm{He}$ insists, however, that, although organizations are players, it is the individual, who, as a member of an organization, makes decisions leading to the establishment, or alteration, of institutions. ${ }^{165}$ Nevertheless, when he describes economic processes he assigns a critically important role to organizations. 'Organizations are a response to the institutional structure of societies, and, in consequence, the major cause of the alteration of that institutional structure.' And he adds:

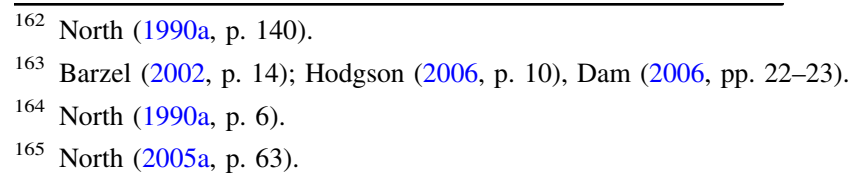


As the organization evolves to capture the potential returns, it will gradually alter the institutional constraints from within. It will do so either indirectly, via the interaction between maximizing behaviour and its effect on gradually eroding or modifying informal constraints; or it will do so directly, via investing in altering the formal rules. ${ }^{166}$

Given these statements, it is surprising that he does not explain the relationship between institutions and organizations. Instead, organizations simply disappear from his theory. Although in Violence and Social Orders he brings organizations back into his conceptualization - as permanently lived organizations - their role is merely as players in an otherwise tranquil environment of open access orders.

There are, undoubtedly, good reasons to explain why North chooses to ignore the link between institutions and organizations. One explanation is that had he developed the notion of organizations as creators of institutions, the clarity and simplicity of his model would have been disturbed. Just as the rationality assumption enables economists to offer a simple, persuasive and powerful explanation about the operation of markets, the exclusion of organizations from his theory could well be seen as a small price to pay for keeping the explanation simple. Some would regard this level of simplification as necessary in order to meet Ockham's Razor test. ${ }^{167}$ While this may well be valid regarding model building, ignoring organizations raises problems for North's theory of institutions. Indeed, ignoring them at the theoretical level, while simultaneously acknowledging that they play a role in establishing and destroying institutions, leaves a major gap in his theory. Indeed, by failing to explain their interaction he takes organizations for granted. This is ironic, because, as already noted, North launched his investigation into institutions in the belief that neoclassical economics cannot explain growth since it takes institutions for granted. Yet, his theory does not account for entities that play an active role in shaping, interpreting and imposing rules of the game. In the absence of an explanation clarifying how institutions are transformed into concrete organizations; how institutional rules become binding on individuals; and how organizations relate to institutions, it is difficult to establish the extent to which his theory helps us to understand institutional and economic change in the real world.

North also fails to explain how individual choices have an impact at the macro level of society. He undoubtedly assumes - in line with the way most economists interpret methodological individualism - that the only valid focus of analysis is on choices made by individuals and that collective choices are merely the aggregation of individual choices. ${ }^{168}$ From this perspective, social systems and social structures disappear and the only object of analysis is the individual. Nevertheless, because he admits that organizations also create institutions, it would appear that he accepts that organizations are social facts independent of individuals. Hence he seems to depart from methodological individualism. Yet, he refuses to reflect on this point and simply states that, even when organizations behave as institutions - that is, when

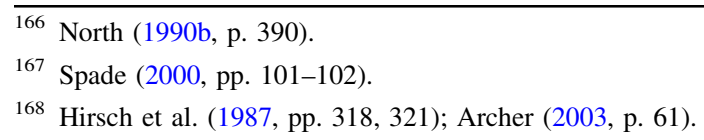


they create rules of the game - those who make choices within the organizations are individuals. ${ }^{169}$ This explanation does not take into account that individuals occupy positions and play roles requiring choices that are collectively determined by them as officers or role players within the organization, not in their individual capacity.

It is well known that organizations play an important role in contemporary societies. It is not necessary to embrace sociological holism to acknowledge this fact. Indeed, James Coleman, one of the leading proponents of methodological individualism in sociology, identifies as urgent the need to account for the role of organizations. ${ }^{170}$ In brief, he argues that contemporary societies have seen the emergence of constructed organizations, a new type of social actor, which has rights and responsibilities that are not immediately linked to natural persons. ${ }^{171}$ Constructed organizations have enormous economic power and the capacity to establish rights and obligations and to influence the direction of political events. According to Coleman, many conservative and liberal social theorists, such as Hayek, mistakenly assume that the path to a prosperous market society requires only minimum political interference by the state. Hence Hayek's opposition to any form of organization established by the state and his celebrated views about the rule of law as a mechanism designed to provide a broad, but unobtrusive framework to support market processes. ${ }^{172}$ There is no doubt that North shares Hayek's views about the role of the state. Indeed, his open-ended and vague conception of institutions seems purposely designed to serve as a general framework that sets minimal conditions for the operation of markets. According to Coleman, however, the view that, in the contemporary world, economic problems can be resolved simply by reducing state interference fails to take into account the overwhelming economic and political importance acquired by organizations. In his view, 'the existence of complex social relations in constructed social organizations makes possible a mode of social control in which rights, constraints, and rewards need not arise from two-party relations, but can be imposed by a third party, the corporate actor'. ${ }^{173}$ As a counterbalance to this new force he proposes building social capital within these organizations, so recreating the solidarity and informality that existed when simpler relations of exchange prevailed. Interestingly, while Coleman calls upon social theorists and economists to take organizations seriously, North, who developed his theory at the same time as Coleman, ignores organizations, introducing instead a notion of institution that is difficult to relate to any concrete social organization. North, of course, does not share Coleman's assessment of constructed organizations as potentially posing a threat to social order. On the contrary, North has no doubt that the emergence of 'permanently lived organizations' is desirable and is an unequivocal indication of progress towards the end goal that all states should be aiming for: the open access order modelled on Western liberal economic and democratic regimes. Regardless of whether Coleman's

\footnotetext{
169 North (2005a, p. 63).

${ }^{170}$ Coleman (1990, pp. 53-578).

171 Coleman (1993, p. 2).

172 Hayek (1973; 1960).

173 Coleman (1991, p. 17).
} 
assessment of the role of organizations is correct, the critical point here is that North's failure fully to incorporate organizations within his framework results in a theory of institutions that is far removed from the real world. As explained, this failing is ultimately linked to his reluctance to shift away from the principles of neoclassical economics and his unwillingness to engage with the findings of other social sciences.

\section{Law}

Law figures prominently in North's theory: it is the main source of the formal rules of the game and plays a crucial role in supporting market exchange. In particular, it provides enforcement mechanisms that help to strengthen the efficacy and credibility of commitments made by economic and political entrepreneurs. Law is also the standard used to identify political regimes and - in its guise as the rule of law - provides the institutional mechanism that facilitates the transition of natural states to open access orders. Thus, law in North's theory is ubiquitous, which is unsurprising since his definition of institutions as rules of the game has strong normative overtones, and it is difficult to distinguish his general concept of formal institutions from legal rules. Yet, despite the seemingly strong affinity between his theory of institutions and the notion of law, it is difficult to assess law's role in his theory. Does he regard law as an independent component or as a mere adjunct to political and economic processes? In order to address this question it is necessary to revisit his distinction between institutions and organizations.

\subsection{Institution or Organization?}

North distinguishes institutions from organizations. Institutions are the rules of the game, while organizations are players in economic, political and social processes. Since North equates formal institutions with legal rules he seems to see law as an institution because institutions create rules of the game. Yet, if this interpretation is correct, it would contradict his assumption that institutions are created only by individuals. Indeed, although most theories of democracy find ways of reconciling legal rules established in a democratic regime with the notion of individual autonomy, legal rules, as a system, are external to the individual and independent of their will. That legal systems are not merely the aggregation of individual wills is widely acknowledged by a diverse group of social theorists, including Karl Marx, Max Weber, Emile Durkheim, Eugene Ehrlich and Talcott Parsons. Indeed, North also seems to accept this view since his other main postulate is the notion of path dependence. The path dependent feature of institutions entails accepting that they persist over time and thus outlive the design or the will of individuals. The so-called permanently lived organizations, which North regards as essential components of open access orders, are permanently lived precisely because they are independent of individual whims or desires. It could, of course, be argued that North's views on the role of individuals in the design of legal institutions are vindicated when the focus of analysis is on discrete legal transactions, such as contracts. This is a view that has 
been considered by social theorists. Indeed, in his well-known critique, Talcott Parsons argues against the utilitarian conception that regards the mutual advantage of the parties as the principal binding force underlying contracts. Drawing on Durkheim's observation about the non-contractual foundations of contract law, Parsons notes that utilitarians fail to notice that contracts.

are actually entered into in accordance with a body of binding rules which are not part of the ad hoc agreement of the parties. The elements included in the utilitarian conception are, on the contrary, all taken into account of in the terms of agreement. What may, however, be called the 'institution' of contract - the rules regulating relations of contract - has not been agreed to by the parties but exists prior to and independently by any such agreement. ${ }^{174}$

In so far as legal institutions create rules of the game, North undoubtedly regards law as an institution. He also considers law as an organization. However, because his theory does not focus on organizations, he has little to say about the way law operates in practice. While acknowledging the overriding importance of contract and property rights, he is not, on the whole, concerned with the way property rights and contract may change overtime. He does, however, note that in pre-modern societies - characterised by dense social networks and localised trade - the protection of property and the enforcement of contracts were not at issue since they were controlled by informal community constraints. ${ }^{175}$ As societies became more complex and trade expanded beyond the immediate community, local constraints lost their efficacy. Thus, in early modern Europe, before the consolidation of nation states, economic agents developed a variety of mechanisms to protect their property and ensure the enforcement of contracts. ${ }^{176}$ These mechanisms, generally described as lex mercatoria or law merchant, are generally regarded as having had a major influence on the development of markets and legal systems in Europe. ${ }^{177}$ According to this view, merchants developed a series of customs in support of their contracting practices, thus enabling them to reduce transaction costs and develop a framework auspicious to extensive impersonal exchange. Thus, by the end of the eleventh century lex mercatoria, as a mechanism designed to coordinate the conflicting interests of merchants and their agents, is said to have governed most commercial transactions. ${ }^{178}$ Recent research casts doubt on this conception of lex mercatoria. In her important book on merchant guilds in medieval Europe, Sheilagh Ogilvie argues that there is no evidence that lex mercatoria was a universally accepted system of commercial law. Lex mercatoria was rarely mentioned in medieval commercial practice and when it was, it referred to a set of procedural rules for prompt and effective conflict resolution. According to Ogilvie, since merchant law was derived from customary practices, there was considerable diversity from one locality to

\footnotetext{
174 Parsons (1968 [1937], p. 311); see also, Durkheim (1964 [1893], pp. 206-219); Palumbo and Scott (2003); Rueschemeyer (2005, pp. 146-147).

175 North (1990a, p. 120).

176 Milgrom et al. (1990).

177 North (1990a, p. 128), Greif (2006, pp. 314, 316).

178 Milgrom et al. (1990, p. 5).
} 
another. The substantive rules of contract law were an amalgam of general principles of Roman Law, statutes issued by local rulers and community custom. ${ }^{179}$ Regardless of the accuracy of North's views about lex mercatoria, it is interesting that his account attributes the emergence of law to the interaction among merchants, rather than to predetermined rules of the game. This interactional perspective on the origins of commercial law, undoubtedly interesting, is not easy to reconcile with his overall theory of institutions. Thus, it is not surprising that he does not develop this line of inquiry, reverting instead to his concept of institution as devices that set rules of the game so that players can perform their pre- assigned roles. Undoubtedly, what attracts him to this interactional interpretation of the origins of lex mercatoria is that it is often used to demonstrate that private ordering is more efficient than the state and is often several steps ahead of the state in finding imaginative solutions to social problems. ${ }^{180}$

North considers law as an organization, but does not explain what type of organization it might be. He seems to regard legal phenomena as isolated events rather than the product of a complex interaction of organizations, legal and nonlegal, that influence the behaviour of individuals, groups and other organizations. Moreover, he also seems to assume that legal rules are routinely obeyed, in which case no further analysis is required. If by chance legal rules are not obeyed (or in his terminology, that formal rules of the game are not followed), this does not impinge on his theory.

From a legal theory perspective, his approach is equivalent to that associated with some forms of legal positivism, which, conceiving legal norms as detached from reality, distinguish between the validity of the norm (rules of the game) and its application in society. The link between the norm and reality, which Hans Kelsen describes as effectiveness, is not a matter for legal science, but for politics or sociology. ${ }^{181}$ Thus, Weber's critique of Rudolf Stammler applies to North, because he also confuses 'the ideal validity of a norm with the assumed validity of a norm in its actual influence on empirical action. The former can be deduced systematically by legal theorists and moral philosophers; the latter, instead, ought to be the subject of empirical observation'. ${ }^{182}$ Eugene Ehrlich, one of the precursors of legal sociology, expresses this distinction as the difference between law in the books and living law. ${ }^{183}$

North is not concerned with the way rules are interpreted or applied. Within his conceptual framework, the world is divided into two groups: rule makers and rule takers. Institutions are rule makers and individuals and organizations are rule takers. There is no room in his theory for conflicting interpretations over the meaning of rules or the behaviour of organizations. He has stated that he is not interested in discussions over the interpretation of rules within organizations, since his main

\footnotetext{
179 Ogilvie (2011, pp. 264-267).

180 Kadens (2012); Michaels (2012).

181 Kelsen (2006 [1949], pp. 41-44); (1960, pp. 272/3).

182 Weber (1978, p. 326).

${ }^{183}$ Ehrlich (2002 [1936]).
} 
concern is the macro aspects of organizations, not their internal structures. ${ }^{184}$ This lack of interest in the behaviour of organizations stems from the fact that he regards organizations as irrelevant to understanding institutional change. His stance reveals a misconception about the way law and legal organizations operate in society, assuming that they are interesting from a micro managerial perspective, but irrelevant for an understanding of macro institutional change. This is consistent with a view that regards legal phenomenon as an isolated event, not the product of a complex interaction of legal, political and economic factors. However, improvements in the protection of property rights in a society, for example, are the outcome of a range of substantive social and economic factors, as well as the interaction of a constellation of institutions. It is because of this complex interaction of societal factors and organizations that major institutional change is difficult to predict and why so often institutional outcomes are unexpected. The main lesson to be drawn from attempts to improve the rule of law in developing countries is that major institutional shifts are difficult to achieve because institutions are interdependent and economic institutions are not the only institutions that have to change in order to bring about improvements in economic performance. Unfortunately, North's decision to exclude organizations from his analysis on managerial grounds fatally undermines his theory's capacity to explain the direction and tempo of institutional change. It also explains why North and his associates have not succeeded in establishing a fruitful dialogue with law and development and socio-legal scholars.

\subsection{Law as a Black Box}

The shortcomings of North's theory are reflected in some of his comments on the way legal systems operate. He acknowledges that the development of reliable and efficient judicial institutions in Europe was a slow process measured in centuries, not decades. ${ }^{185} \mathrm{He}$ also concedes that, even in countries with efficient and honest judicial systems, judges and courts are not infallible. After all, he regards judges as agents subject to the perennial conflict of interest that characterises principal/agent relationships. They have their own utility function so their decisions are often determined by their own interests. ${ }^{186}$ Thus, he has no sympathy for those who hold that some legal systems are inherently more efficient than others or that the nature of a legal system can have fatal consequences for the future development of the country. ${ }^{187}$ In particular, he rejects the argument that the common law is inherently efficient. In his view, if courts in common law systems happen to make efficient decisions it is because the competitive process leads judges to the correct outcome, rather than because of any intrinsic feature of the common law. ${ }^{188}$

\footnotetext{
184 North's statement is a personal communication to Geoffrey Hodgson and is reproduced in Hodgson (2006, p. 19).

185 North (1990a, p. 128).

186 North (1990a, p. 58); (1981, pp. 40-41).

187 La Porta et al. (2008); Botero et al. (2004); for a critique of this approach, see Dam (2006, pp. 26-49).

188 North (1990a, p. 97).
} 
It is difficult to disagree with his view that legal systems are neither inherently efficient nor inefficient. The problem, however, is that, by dismissing the efficiency theory of the common law, he also rejects the view that law, as an institution, plays a role in shaping political and economic outcomes. Indeed, from his perspective, it seems that law is little more than an empty vessel performing the predetermined function of protecting property rights and enforcing contracts. He has no interest in the way law performs its pre-assigned function because he regards economic and political processes as the main drivers of social outcomes.

North's views on law have a functionalist ring about them, characteristic among some comparative lawyers. ${ }^{189}$ They also have an affinity with the views attributed to orthodox Marxists, who regard law as a mere epiphenomenon, incidental to the all-important economic processes. ${ }^{190}$ Since North does not believe that law and legal systems play a significant role in shaping the evolution of institutions, he is not interested in examining how law accomplishes its preordained function. Indeed, he regards law and the legal system as a 'black box', designed to processes political and economic inputs, but with no internal dynamic worthy of analysis. It is therefore not surprising that, when discussing the evolution of the US Supreme Court's case law in critical areas he attributes it to changes in the subjective perceptions of judges: 'From the Marshall Court (1801 to 1835 ) to the Renquist Court, the justices have interpreted and reinterpreted essentially the same set of rules. The Court reverses itself 180 degrees over time because the judges' subjective modelling of the issues changes.' ${ }^{191}$ There is no hint in this passage that he regards the Supreme Court's changing relationship with other organs within the Federal Government as having any bearing on the evolution of its case law. In Violence and Social Orders, he again rejects the view that law might have an impact on institutional development. Indeed, he flatly dismisses the notion that the introduction of a bill of rights or the universal franchise in a developing country would improve the chances of development. ${ }^{192}$ In this he is not restating the undisputed platitude that the enactment of legal rules is insufficient to bring about social and economic change. Instead, his statement suggests that he categorically dismisses even the possibility of a legal mechanism as important as the bill of rights having an impact on the process of political and economic development and is unaware of the significant impact of constitutional courts on the political systems of many developing countries. ${ }^{193}$ Two prominent examples include Colombia and South Africa, where constitutional litigation over civil and political rights has become an important factor in the process of institutional change. ${ }^{194}$

That North does not believe that legal structures have an impact is borne out by what he believes is the reason behind the freedom enjoyed by US citizens. This

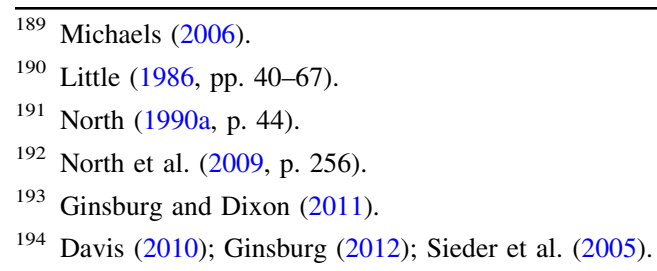


issue was raised by William Riker in response to a paper by Vincent Ostrom. ${ }^{195}$ In his paper Ostrom argues that the reason why Americans enjoy freedom is because of the institutions established by the constitution. ${ }^{196}$ Riker disagrees. In his view, the reason why the US enjoys so much freedom is because its citizens love freedom, not because of the merits of the constitution. Riker's views are perfectly valid, especially for someone sceptical about the role of institutions. Surprisingly, however, North endorses Riker's position. ${ }^{197}$ This endorsement is problematic because it contradicts his key assumption that institutions matter because they shape and influence political and economic outcomes. North does not of course deny that law plays a role, but the role he assigns to it is minor, not dynamic. Legal institutions are either barriers, or conduits, to secure the implementation of decisions taken elsewhere. Thus, in his view, legal institutions have no capacity to bring about independent outcomes. They have no autonomy: they are merely 'black boxes' that respond to external economic or political inducements.

If the foregoing analysis is correct, what are the implications for North's theory? If law is a mechanism that performs pre-ordained functions in a mechanical fashion, but makes no independent contribution to the pace or direction of institutional change, why does it seem to occupy such a prominent place in North's institutional theory? Why is he so concerned with property rights, contract law and legal enforcement mechanisms? The preceding analysis suggests that legal mechanisms are forever present in his theory, but only in a supporting role. Their role is merely to assist in the implementation of political and economic outcomes determined by political and economic entrepreneurs. If so, where does law, as an institution, come from? North's answer is that law is closely related to political power and was historically, a device to enforce the privileges of elites. In developed capitalist democracies, the extension of the rights to all citizens came about when the elites found it in their interest to transform their privileges into impersonal rights. ${ }^{198}$ Thus, law's role is limited to supplying the rules of the game. Once it has performed this function, it fades away to become a mere organization subject to the vicissitudes of the evolving relationship between political and economic elites. This conception is defensible, but difficult to reconcile with his view that institutions - all institutions are humanly devised constraints that shape human interaction and hence impact on economic growth.

From a socio-legal perspective, North's approach to law and legal organizations is ambiguous, incomplete and misleading. It is ambiguous because he regards legal organizations as players, and, occasionally, as institutions, but does not explain how and when such transformation occurs. It is incomplete because it focuses exclusively on formal rules, while ignoring their impact on society. It is misleading because its conception of law is managerial, offering an oversimplified picture of legal and institutional change. Ultimately, his approach to law allows him to ignore

\footnotetext{
195 Riker (1976, pp. 13-15).

196 Ostrom (1976).

197 North (1990a, pp. 59-60).

198 North et al. (2009, p. 63).
} 
the operation of the legal process, while simultaneously proclaiming that property and contract, albeit in purely formal terms, are relevant to economic growth.

\subsection{Rule of Law Assistance}

Given North's view on the role of law in institutional change, it is pertinent to ask where he stands on the issue of legal technical assistance of the type provided by multilateral banks, international donors and international non-governmental organizations. Despite his scepticism about the likelihood of poor countries ever developing efficient institutional frameworks, his work is highly regarded by international institutions, especially the World Bank, OECD and USAID. His work is often cited in World Bank documents, in particular Institutions, Institutional Change and Economic Performance. ${ }^{199}$ His recent book, Violence and Social Orders has also influenced the Bank's analysis of state building, justice and security in fragile states. ${ }^{200}$ In general, his work has, undoubtedly, been a major factor in helping the Bank's shift towards governance, prompting the development of a series of initiatives under the motto 'governance matters'.

North's influence on World Bank thinking is, to some extent, surprising. Indeed, despite supporting economic deregulation and liberalization policies, he has never shared the simplistic assumptions associated with the original Washington Consensus. Indeed, he has made an effort explicitly to distance himself from it in some of his publications. ${ }^{201}$ His argument is that Washington Consensus policies were misguided, both in their conception and in their application. They were conceptually misguided because the promoters of the Washington consensus assumed that the principles of neoclassical economics ('getting the prices right') could be applied anywhere in the world. They applied their economic recommendations without taking into account the prevailing political cultural and ideological context, on the assumption that individuals and institutions throughout the world would respond favourably. Thus, in North's view, these policy recommendations were flawed. He proposes instead that the principles of neoclassical economics should be supplemented with a realistic, dynamic and historically accurate theory of institutions.

North's unequivocal dislike of state-driven policies and his strong focus on markets have certainly contributed to boost his reputation among policy-makers at the World Bank. Markets, in his view, require governments, but not just any government.

There must be institutions that limit governments from preying on the market. Solving the development problem therefore requires the crafting of political institutions that provide the necessary underpinnings of public goods essential for a well-functioning economy and at the same time limit

\footnotetext{
199 World Bank (2006); (1997).

200 World Bank (2011).

201 North et al. (2009, p. 271).
} 
the discretion and authority of government and of the individual actors within governments. ${ }^{202}$

This statement, however, does not imply that he accepts the neoliberal project, as embodied in the Washington Consensus. Indeed, he is especially critical of libertarian economists, who believe that under ideal laissez faire conditions, property rights and the rule of law can operate efficiently without the need for adjustment. Such a view, he argues, is untenable because conditions for market efficiency vary over time in line with changes in technology, human capital and information costs. ${ }^{203}$

North acknowledges that today developing countries have a daunting task, expected as they are to implement institutional changes that took Western countries centuries to achieve. ${ }^{204}$ His theory, however, does not offer a formula for achieving political and economic change. Accordingly he is sceptical about development assistance being capable of resolving the economic and political problems faced by recipient countries. This scepticism stems from his view that institutions embody human intentionality, so neither they nor markets are natural and, hence, cannot be expected to operate in accordance with predetermined plans. ${ }^{205}$ Nevertheless, in Understanding the Process of Economic Change, he concludes, somewhat gloomily, that despite the uncertainty about institutional outcomes 'we have no choice but to undertake social engineering'. ${ }^{206}$ While he reluctantly goes along with piece-meal social engineering, he is, nonetheless, critical of the legal and institutional reform programmes implemented in recent years. He emphasises that development policies based on Western models (open access order countries) should not be indiscriminately applied to achieve institutional improvements in developing countries (natural states). ${ }^{207}$ Transplanting institutions modelled on developed country institutions to developing countries is misguided because the transplants do not generally work as expected and, worse, they can even disrupt the social order in those countries. ${ }^{208}$

\section{Conclusion}

What lessons can lawyers draw from North's theory of institutions? Why should his work be of interest to lawyers if he regards law as a mere adjunct to economic and political processes? This section restates some of the points developed in the paper and considers these two questions.

\footnotetext{
202 North (2005, p. 85).

203 North (2005, p. 122).

204 North (2005, p. 120).

205 North (2005, p. 162).

206 North (2005, p. 162).

207 North et al. (2009, p. 271).

208 North et al. (2009, p. 265).
} 
From the perspective of law and development, North's conceptualization of institutions has many positive features: it regards law as an institution embedded in society; it highlights the relevance of history for an understanding of institutional and legal processes; it pays close attention to cultural heritage as a source of societal norms; it acknowledges the role of belief systems in validating institutional arrangements; it highlights the close link between political and economic processes; it is sceptical about the benefits of imposing institutions on developing countries; and last, but significantly, it highlights the role of individuals in the process of institution building and institutional reform. Despite such positive features, his theory also has shortcomings, which have been discussed in the preceding sections. For the purpose of this section, I highlight the following: the failure clearly to explain the provenance of institutions; the confusing distinction between formal and informal institutions; the vague and poorly developed distinction between institutions and organizations; the failure to offer a convincing explanation of the link between economic and political processes; the disregard of dynamic features of law as an institution; the assumption that some legal institutions, such as property and contract, have attributes that are valid across history and cultures; and the supposition that all societies should transit to the same end goal: the open access order model.

Although North regards law's role as secondary to the all-important economic and political processes, he acknowledges that law is an originator of institutions.

Nevertheless, he does not explain the role of law and is not interested in the way organizations work. He is only interested in macro institutional dynamics. His theory, however, does not offer a satisfactory account of the interplay of institutions at the macro level. Indeed, he does not take into account that institutions, especially legal institutions, are part of a complex network of institutions and therefore institutional and societal outcomes are rarely caused by the operation of a single institution. This is why his views about the role of efficient property rights is unconvincing, as confirmed by the comments of several historians and development economists. North explains macro institutional interaction through his analysis of the link between political and economic processes. Unable to explain this interaction by merely aggregating the interests of individual entrepreneurs, he builds a theory of political development that explains institutional change in terms of an endless process of elite manoeuvring. His theory, however, does not identify substantive economic or political factors that bring about institutional change. In particular, it does not explain how institutions in natural states evolve to become open access orders. Instead, his theory attributes institutional outcomes to the selfinterested behaviour of members of the elite, rather than to structural features of the economy or polity of natural states. Thus, institutional change, if it occurs is random, as is dependent on the subjective preferences of members of the elite.

North ignores one of the main postulates of his theory, which is that institutions are created and destroyed by individuals, by embracing an elitist theory of politics. Although members of the elite are individuals, they neither represent all individuals in a particular society, nor do they act in their individual capacity when responding strategically to the maximizing behaviour of competing coalitions of elites. It seems ironic that a theory that claims to place individuals as the main agents in the creation 
of institutions ends up relying on a theory of collective choice that all but negates individual autonomy. The notion that a small band of people - the elite - designs, operates and destroys institutions is incompatible with the view that institutions are mechanisms created by individuals.

A point of special interest for law and development scholars is the role of law in North's theory of political development. In natural states, law is little more than a tool elites use to exchange privileges and control the polity. Thus, in these regimes, law and politics are not differentiated. By contrast, in open access orders law is transformed and converted into the familiar 'rule of law' prevalent in liberal democracies. North does not, however, explain the factors that lead to this critical transformation. Although he suggests that, at a certain stage, elites rely on legal procedures to manage competition, he does not explain what prompts them to choose this procedure. Neither does he explain whether this choice has an impact on the eventual transition to an open access order. Does the transformation of law from a blunt political instrument into an institutional framework resembling the ideals of the rule of law have anything to do with changes taking place in the economy? Curiously, he does not discuss this point. As a consequence, legal scholars in search for clues as to whether particular economic policies and structures might contribute to consolidating and expanding the role of legal institutions will not find answers in his theory.

Absent from North's theory is any attempt to take into account the historical trajectory of developing countries or the problems they face today. A careful study of the development of law and legal institutions in these states might show that legal institutions interact with political and economic structures in complex and interesting ways. North, however, is not interested in examining the progress of institutions anywhere other than in successful market economies. As a consequence, his theory has nothing meaningful to say about political and legal processes in natural states.

Ultimately, the implicit message is that citizens in natural states can only hope that their elites either realise that it is in their interest to develop an open legal system or are enlightened enough to allow international agencies to design institutions similar to those prevailing in open access orders.

In the preceding section I noted the similarities between North's theory of institutions and legal positivism. Relevant to the study of law in developing countries is that both North and legal positivists share a view of institutions that overly simplifies the concept of law. Indeed, North assumes that formally enacted rules of the game are consistent and, in general, obeyed. His theory, however, does not account for social relations governed by local practices. There is thus no room in his theory for an understanding of the informal sector of the economy, prevalent in most developing countries. Legal positivism ignores this dimension of social relations because, from its perspective, only formally enacted rules count as law. North also ignores it, because he considers the interpretation of conflicting social practices as irrelevant for an understanding of macro-institutional relations. In any event, the problem of informal law in developing countries is not easy to reconcile with North's distinction between institutions and organizations. 
The absence in North's framework of any reference to the consequences of globalization for developing countries is perhaps the single most important omission. This is surprising since one of the factors prompting his interest in institutions was the impact of overseas trade on polities in early modern Europe. Given the influence of globalization on policy-making worldwide, it would seem that any assessment of institutions in developing countries cannot disregard the importance of global governance structures on institutions at the national level.

Although North's attempt to produce a conceptual framework to study institutions and economic change was not entirely successful, law and development scholars will find in his work a wealth of insights and perspectives that will enrich their research. It is interesting to recall that the law and development movement that emerged in the United States in the 1960s was abruptly abandoned when its main proponents realised that understanding the role of law in developing countries was not as straightforward as expected. Their retreat opened the way for economists, who, encouraged by the wave of economic globalization and political change brought about by the collapse of the Soviet Union, began to generate facile policy advice on how to improve legal systems and institutions in developing countries. North did not agree with their simplistic policy recommendations. Instead, he constructed a theory of institutions grounded in history. Although he encountered many conceptual problems while building his theory he did not give up and continued to refine his conceptual framework until the end of his long and productive life.

Open Access This article is distributed under the terms of the Creative Commons Attribution 4.0 International License (http://creativecommons.org/licenses/by/4.0/), which permits unrestricted use, distribution, and reproduction in any medium, provided you give appropriate credit to the original author(s) and the source, provide a link to the Creative Commons license, and indicate if changes were made.

\section{References}

Adelman I (2001) Fallacies in development theory and their implication for policy. In: Meier GM, Stiglitz JE (eds) Frontiers of development economics. Oxford University Press, Oxford, pp 103-134

Allen DW (2000) Transaction costs. In: Bouckaert B, De Geest G (eds) Encyclopedia of law and economics (volume I). E.E Elgar, Cheltenham, pp 893-926

Alston LJ (2008) New institutional economics. In: Durlauf SN, Blume LE (eds) The new Palgrave dictionary of economics, vol 6, 2nd edn. Palgrave Press, London, pp 32-37

Ankarloo D (2002) New institutional economics and economic history. Cap Class 26:9-36

Archer M (2003) Being human: the problem of agency. Cambridge University Press, Cambridge

Bardhan P (2001) Distributive conflicts, collective action, and institutional economics. In: Meier GM, Stiglitz JE (eds) Frontiers of development economics. Oxford University Press, Oxford, pp 269-290

Bardhan P (2005) Scarcity, conflicts and cooperation-essays in the political and institutional economics of development. MIT Press, Cambridge

Barzel Y (2002) A theory of the state. Cambridge University Press, Cambridge

Bates R (2014) The new institutionalism. In: Galiani S, Sened I (eds) Institutions, property rights, and economic growth: the legacy of Douglass North. Cambridge University Press, Cambridge, pp 50-65

Bendix R (1977 [1964]) Nation building and citizenship. University of California Press, Berkley, pp 89-126

Bendix R (1978) Kings or people-power and the mandate to rule. University of California Press, Berkley 
Blaug M (1992) The methodology of economics, 2nd edn. Cambridge University Press, Cambridge Botero JC, Djankov S, La Porta R, Lopez-de-Silanes F, Shleifer A (2004) The regulation of labor. Quart J Econ 119(4):1339-1382

Brewer J (1988) The English state and fiscal appropriation, 1688-1789. Polit Soc 16(2-3):335-385

Bromley DW (1989) Property relations and economic development: the other land reform. World Dev 17(6):867-877

Bromley DW (2009) Formalising property relations in the developing world: the wrong prescription for the wrong malady. J Land Use Policy 26(1):20-27

Bunge Mario (2000) Ten Modes of Individualism- None of Which Works-and Their Alternatives. Philos Soc Sci 30:384-406

Chang H-J (2011) Institutions and economic development: theory, policy and history. J Inst Econ 4:1-26

Clark G (1993) Economic growth in history and theory. Theory Soc 22(6):871-886

Coase RH (1937) The nature of the firm. Econ New Ser 16:386-405

Coase RH (1960) The problem of social cost. J Law Econ 3:1-44

Coase RH (1994) The institutional structure of production, prize lecture: the Sveriges Riksbank prize in economic sciences in memory of Alfred Nobel 1991. In: Coase RH (ed) Essays on Economics and Economists. University of Chicago Press, Chicago, pp 3-14

Coleman JS (1990) Foundations of social theory. Harvard University Press, Cambridge

Coleman JS (1991) Constructed organization: first principles. J Law Econ Organ 7:7-23

Coleman JS (1993) The rational reconstruction of society Coleman. Am Sociol Rev 58:1-15

Congost R (2003) Property rights and historical analysis: what rights? What History. Past Present $81: 35-72$

Crafts N (2010) Explaining the first industrial revolution: two views. Eur Rev Econ Hist 15:153-168

Dam KW (2006) The law growth nexus: the rule of law and economic development. Brookings Institution Press, Washington

Daunton M (2010) Rationality and institutions: reflections on Douglass North. Struct Change Econ Dyn $21: 147-156$

Davis DM (2010) South African constitutional jurisprudence: the first fifteen years. Ann Rev Law Soc Sci 6:285-300

Demsetz H (2000) Dogs and tails in the economic development story. In: Ménard C (ed) Institutions, contracts and organizations: perspectives from new institutional economics. Edward Elgar, Cheltenham, pp 69-87

Demsetz H (2008) From economic man to economic system. Cambridge University Press, Cambridge

Denzau AT, North DC (1994) Shared mental models: ideologies and institutions. Kyklos 47((Fasc 1)):3-31

Dugger WM (1995) Douglass C. Norths new institutionalism. J Econ Issues 29(2):453-458

Durkheim E (1964) The division of labor in society. Free Press, New York 1893

Edwards J, Ogilvie S (2012) Contract enforcement institutions and social capital: the Maghribi traders reappraised. Econ Hist Rev 65(2):421-444

Eggertsson T (1990) Economic behaviour and institutions. Cambridge University Press, Cambridge

Ehrlich E (2002) Fundamental principles of the sociology of law. Transaction Publishers, New Brunswick 1936

Engerman SL, Sokoloff KL (2005) Institutional and non-institutional explanations of economic differences. In: Ménard C, Shirley MM (eds) Handbook of new institutional economics. Springer, Berlin, pp 639-665

Ertman T (1997) Birth of the leviathan. Harvard University Press, Cambridge

Fenoaltea S (1975a) The rise and fall of a theoretical model: the Manorial system. J Econ Hist 35:386-409

Fenoaltea S (1975b) Authority, efficiency, and agricultural organization in medieval England and beyond: a hypothesis. J Econ Hist 35(4):693-718

Field AJ (1981) The problem with neoclassical institutional economics: a critique with special reference to the North/Thomas model of pre-1500 Europe. Explor Econ Hist 18:174-198

Field AJ (1999) New economic history and law and economics. Elgar Encyclopedia of law and economics. E.E. Elgar, Cheltenham, pp 728-753

Field AJ (2006) North, Douglass. In: Clark DA (ed) Elgar companion to development studies. E.E. Elgar, Cheltenham, pp 423-426

Furubotn EG, Richter R (2005) Institutions and economic theory: the contribution of the new institutional economics, 2nd edn. University of Michigan Press, Ann Arbor 
Ginsburg T (2012) Court and new democracies. Law Soc Inq 37(3):720-742

Ginsburg T, Dixon R (eds) (2011) Comparative constitutional law. E.E. Elgar, Cheltenham

Goldstone JA (2002) Efflorescences and economic growth in world history: rethinking the rise of the West and the industrial revolution. J World Hist 13(2):323-389

Greif A (2006) Institutions and the path to the modern economy: lessons from medieval trade. Cambridge University Press, Cambridge

Greif A (2008) North Douglass Cecil. In: Durlauf SN, Blume LE (eds) The new Palgrave dictionary of economics, 2nd edn, vol 6, pp 131-134

Greif A (2012) The Maghribi traders: a reappraisal? Econ Hist Rev 65(2):445-469

Harris R (2004) Government and the economy, 1688-1850. In: Floud R, Johnson P (eds) Cambridge economic history of Britain. Cambridge University Press, Cambridge, pp 204-237

Kincaid H (2004) Methodological individualism and economics. In: Davis JB, Marciano A, Runde J (eds) Elgar companion to economics and philosophy, Cheltenham, E E Elgar, pp 299-314

Hayek FA (1960) The constitution of liberty. Routledge, London

Hayek FA (1973) Law, legislation and liberty, vol 1. Routledge, London

Hicks J (1974) The rise of the Western world: a new economic history by DC North and RP Thomas. Econ Hist Rev 27(4):692-694

Hilton R (1980) Individualism and the English peasantry. New Left Rev I/120:109-111

Hirsch PM, Lounsbury MD (1996) Rediscovering volition: the institutional economics of Douglass C. North. Acad Manag Rev 21(3):872-884

Hirsch PM, Michaels S, Friedman R (1987) 'Dirty hands' versus 'clean models': is sociology in danger of being seduced by economics? Theory Soc 16(3):317-336

Hodgson GM (2006) What are institutions? J Econ Issues 40(1):1-25

Hoppit J (2011) Compulsion, compensation and property rights in Britain, 1688-1833. Past Present 210:93-128

Jones A (1972) The rise and fall of the manorial system: a critical comment. J Econ Hist 32(4):938-944

Kadens E (2012) The myth of the customary law merchant. Texas Law Rev 90:1153-1206

Kahan A (1973) Notes on serfdom in Western and Eastern Europe. J Econ Hist 33(1):86-99

Kelsen H (1960) What is the pure theory of law? Tulane Law Rev 34:269-276

Kelsen H (2006 [1949]) General theory of law and state. Transaction Publishers, New Brunswick

Khalil EL (2012) Why Europe? A critique of institutionalist and culturalist economics. J Econ Surv 26(2):351-372

Kleinfeld R (2012) Advancing the rule of law abroad. Carnegie Endowment for International Peace, Washington, DC

Knight J, North DC (1997) Explaining economic change. Leg Theory 3:211-226

La Porta R, Lopez-de-Silanes F, Shleifer A (2008) The economic consequences of legal origins. J Econ Lit 46(2):285-332

Lane FC (1979) Profits from power. State University of New York Press, Albany

Lawson-Remer T (2013) Property insecurity. Brooklyn J Int Law 38(1):145-191

Lipsey RG, Carlaw KI, Beakar CT (2005) Economic transformations. Oxford University Press, Oxford Little D (1986) The scientific Marx. University of Minnesota Press, Minneapolis

Mantzavinos C, North DC, Shariq S (2003) Learning, institutions, and economic performance. Max Planck Institute for Research on Collective Goods. http://ssrn.com/abstract=510902

McCloskey DN (2010) Bourgeois dignity: why economics can't explain the modern world. University of Chicago Press, Chicago

McFarlane A (1978) The origins of English individualism: the family property and social transition. Blackwell, Oxford

Medema SG (1999) Legal fiction: the place of the Coase theorem in law and economics. Econ Philos $15: 209-233$

Medema SG (2011) The Coase theorem lessons for the study of the history of economic thought. J Hist Econ Thought 33(1):1-18

Ménard C, Shirley MM (eds) (2005) Handbook of new institutional economics. Springer, Dordrecht

Ménard C, Shirley MM (2012) New institutional economics from early intuition to a new paradigm? Ronald Coase Institute Working Paper no. 260 pp

Ménard C, Shirley MM (2014) The contribution of Douglass C. North to new institutional economics. In: Galiani S, Sened I (eds) Institutions, property rights, and economic growth: the legacy of Douglass North. Cambridge University Press, Cambridge, pp 11-29 
Mercuro N, Medema SG (2006) Economics and the law-from Posner to postmodernism and beyond, 2nd edn. Princeton University Press, Princeton

Michaels R (2006) The functional method of comparative law. In: Reimann M, Zimmermann R (eds) The Oxford handbook of comparative law. Oxford University Press, Oxford, pp 339-382

Michaels R (2012) Legal medievalism in lex mercatoria scholarship. Texas Law Rev 90:259-268

Milgrom PR, North DC, Weingast BR (1990) The role of institutions in the revival of trade: the law merchant, private judges, and the champagne fairs. Econ Polit 2(1):1-23

Milonakis D, Fine B (2007) Douglass Norths remaking of economic history: a critical appraisal. Rev Radic Polit Econ 39(1):27-57

Mokyr J (2005) The intellectual origins of modern economic growth. J Econ Hist 65(2):285-351

Mokyr J (2009) Intellectual property rights, the industrial revolution, and the beginnings of modern economic growth. Am Econ Rev (Pap Proc) 99(2):349-355

Moore B Jr (1966) Social origins of dictatorship and democracy. Beacon Press, Boston

Myrdal G (1978) Institutional economics. J Econ Issues 12(4):771-783

Nelson RR (2002) The problem of market bias in modern capitalist economies. Ind Corp Change 11(2):207-244

North DC (1971) Institutional change and economic growth. J Econ Hist 31(1):118-125

North Douglass C (1977) Markets and Other Allocation Systems in History: the Challenge of Polanyi. J Eur Econ Hist 6(3):703-717

North DC (1979) A framework for analyzing the state in economic history. Explor Econ Hist 16:249-259

North DC (1981) Structure and change in economic history. W.W. Norton, New York

North DC (1984) Transaction costs, institutions, and economic history. J Inst Theor Econ 140:7-17 (also In: Furubotn EG, Richter R (eds) (1991) The new institutional economics. Mohr Siebeck, Tubingen, pp 203-213)

North DC (1989) Institutions and economic growth: an historical introduction. World Dev 17(9):1319-1332

North DC (1990a) Institutions, institutional change, and economic performance. Cambridge University Press, Cambridge

North DC (1990b) Institutions and their consequences for economic performance. In: Schweers Cook K, Levi M (eds) The limits of rationality. University of Chicago Press, Chicago, pp 383-401

North DC (1991) Institutions. J Econ Perspect 5(1):97-112

North DC (1992) Transaction costs, institutions, and economic performance. International Centre for Economic Growth, San Francisco, Occasional Paper No 30, p 33

North DC (1993) Institutions and credible commitment. J Inst Theor Econ 149:11-23

North DC (1994) Economic performance through time. Am Econ Rev 84(3):359-368

North DC (1996) Epilogue: economic performance through time. In: Lee A, Thrainn Eggertsson J, North DC (eds) Empirical studies in institutional change. CUP, Cambridge, pp 342-355

North DC (1997) Understanding economic change. In: Nelson JM, Tilly C, Walker L (eds) Transforming post-communist political economies. National Academy Press, Washington, DC, pp 13-18

North DC (2003) Markets. In: Mokyr J (ed) The Oxford encyclopedia of economic history. Oxford University Press (e-reference edition), Oxford

North DC (2005a) Understanding the process of economic change. Princeton University Press, Princeton

North DC (2005b) Institutions and the performance of economics over time. In: Ménard C, Shirley MM (eds) Handbook of new institutional economics. Springer, Dordrecht, pp 21-30

North DC (2006) Cognitive science and the study of the 'rules of the game' in a world of uncertainty. In: Drobak JN (ed) Norms and the law. Cambridge University Press, Cambridge, pp 48-56

North DC, Thomas RP (1971) The rise and fall of the manorial system: a theoretical model. J Econ Hist 31(4):777-803

North DC, Thomas RP (1973) The rise of the Western world: a new economic history. Cambridge University Press, Cambridge

North DC, Weingast BR (1989) Constitutions and commitment: the evolution of institutions governing public choice in seventeenth-century England. J Econ Hist 49(4):803-832

North DC, Wallis JJ, Weingast BR (2009) Violence and social orders: a conceptual framework for interpreting recorded human history. Cambridge University Press, Cambridge

Ogilvie S (2007) Whatever is, is right? Economic institutions in pre-industrial Europe. Econ Hist Rev 60(4):649-684

Ogilvie S (2011) Institutions and European trade merchant guilds, 1000-1800. Cambridge University Press, Cambridge 
Ostrom V (1976) The American experiment in constitutional choice. Public Choice 27:1-12

Ostrom E (1990) Governing the commons. Cambridge University Press, Cambridge

Ostrom E (2005) Understanding institutional diversity. Princeton University Press, Princeton

Palumbo A, Scott A (2003) Weber, Durkheim and the sociology of the modern state. In: Ball T, Bellamy

R (eds) The Cambridge history of twentieth-century political thought. Cambridge University Press, Cambridge, pp 368-391

Parsons T (1968 [1937]) The structure of social action, vol 1. The Free Press, New York

Pincus SCA (2009) 1688: The first modern revolution. Yale University Press, New Haven

Pincus SCA, Robinson JA (2014) What really happened during the glorious revolution. In: Galiani S,

Sened I (eds) Institutions, property rights, and economic growth: the legacy of Douglass North. Cambridge University Press, Cambridge, pp 192-222

Platteau J-P, Hayami Y (1998) Resource endowments and agricultural development: Africa versus Asia. In: Hayami Y, Aoki M (eds) The institutional foundations of East Asian economic development. St. Martins Press, New York, pp 357-412

Plucknett TFT (2010) [1956] A concise history of the common law. Liberty Fund, Indianapolis

Pocock JGA (1980) The origins of English individualism: the family property and social transition. Hist Theory 19(1):100-105

Przeworski A (2004) The last instance: are institutions the primary cause of economic development? Eur J Sociol 45(2):165-188

Richardson G, Bogart D (2008) Institutional adaptability and economic development: the property rights revolution in Britain, 1700 to 1830. National Bureau of Economic Research, Cambridge, MA, Working Paper 13757, $51 \mathrm{pp}$

Riker W (1976) Comments on Vincent Ostroms paper. Public Choice 27:13-15

Rinngrose DR (1973) European economic growth: comments on the North-Thomas theory. Econ Hist Rev (New Ser) 26(2):285-292

Rodrik D, Subramanian A, Trebbi F (2004) Institutions rule: the primacy of institutions over geography and integration, economic development. J Econ Growth 9:131-165

Rueschemeyer D (2005) Building states-inherently a long-term process? An argument from theory. In: Rueschemeyer D, Lange M (eds) States and development: historical antecedents of stagnation and advance. Palgrave, New York, pp 143-164

Rutherford M (1989) What is wrong with the new institutional economics (and what is still wrong with the old)? Rev Polit Econ 1(3):299-318

Rutherford M (1994) Institutions in economics—-the old and new institutionalism. Cambridge University Press, Cambridge

Schlag P (1989) The problem of transaction cost. South Calif Law Rev 62:1661-1700

Schumpeter JA (1934) The theory of economic development. Harvard University Press, Cambridge

Schumpeter JA (1980 [1938]) Methodological individualism. Institutum Europaeum, Brussels

Sieder R, Schjolden L, Angell A (2005) The judicialization of politics in Latin America. Palgrave, New York

Spade PV (2000) Ockhams nominalist metaphysics: some main themes. In: Spade PV (ed) The Cambridge companion to Ockham. Cambridge University Press, Cambridge, pp 100-117

Stasavage D (2002) Credible commitment in early modern Europe: North and Weingast revisited. J Law Econ Organ 1(1):155-186

Stromberg JR (2002) Douglass C. North and non-Marxists institutional determinism. J Libert Stud 16(4):101-137

Thomas C (2011) Law and neoclassical economic development in theory and practice: toward an institutionalist critique of institutionalism. Cornell Law Rev 96:967-1024

Tian G (2000) Property rights and the nature of Chinese enterprises. J Comp Econ 28:247-268

Toye J (2008) Exploring utopia (limited) with a companion. Camb J Econ 32:513-525

Trebilcock MJ, Daniels RJ (2008) Rule of law reform and development: charting the fragile path of progress. E.E. Elgar, Cheltenham

Udehn L (2002) The changing face of methodological individualism. Ann Rev Sociol 28:479-507

Weber M (1961 [1923]) General economic history. Collier Books, New York

Weber M, Roth G, Wittich C (eds) (1978) Economy and society, vol I. University of California Press, Berkeely

Williamson OE (1985) The economic institutions of capitalism: firms, marketing, relational contracting. Free Press, New York

Williamson OE (1995) Economy: an economic perspective. Ind Corp Change 4(1):21-49 
Williamson OE (2005) The economics of governance. Am Econ Rev 95(2):1-18

World Bank (1997) World development report: the state in a changing world. World Bank, Washington World Bank (2006) World development report: equity and development. World Bank, Washington

World Bank (2011) World development report: conflict, security and development. World Bank, Washington

Zamagni $\mathrm{V}$ (2010) What is the message of 'understanding the process of economic change' for economic historians? Struct Change Econ Dyn 21:157-163

Zhang M (2008) From public to private: the newly enacted Chinese property law and the protection of property rights in China. Berkeley Bus Law J 5(2):317-363

Zouboulakis M (2005) On the evolutionary character of Norths idea of institutional change. J Inst Econ 1(2):139-153 